\title{
Tests of amounts and times of application of nitrogen and of sequential sprays of aphicide and fungicides on winter wheat, following either beans or wheat, and the effects of take-all (Gaeumannomyces graminis var. tritici), on two varieties at Saxmundham, Suffolk 1980-3
}

\author{
By F. V. WIDDOWSON, A. PENNY, R. J. GUTTERIDGE, R. J. DARBY \\ AND M. V. HEWITT \\ Rothamsted Experimental Station, Harpenden, Herts., $A L 52 J Q$
}

(Received 31 January 1985)

\begin{abstract}
SUMMARY
From 1980 to 1983 factorial experiments at Saxmundham were made on winter wheat following beans, so as to minimize losses from foot and root rots and increase potential yields. All tested seed-bed $\mathrm{N}$, and amounts and times of application of $\mathrm{N}$ in spring, both with and without sprays intended to limit losses from aphids and from diseases. The tests were made on one semi-dwarf variety in 1980 and on two contrasting varieties from 1981 to 1983 . In 1982 and 1983 a comparison was made between wheat following beans and wheat following wheat; all treatments were applied cumulatively to the two successive wheat crops.

In 1980 and in $1981 \mathrm{~N}$ given in March greatly increased the number of shoots in April but had little effect on the final number of ears. Yields of grain were greatly increased by $\mathbf{N}$ given during April and by sequential sprays with fungicides and aphicide; these two factors interacted so that responses to $\mathrm{N}$ were larger with the sprays than without. Yield responses to seed-bed $N$, although small, were greater than the benefits from applying divided instead of single $\mathbf{N}$ dressings in spring. The number of ears was greatly increased by increasing the amount of $\mathrm{N}$ given in April, but only slightly by any of the other treatments. The weight of 1000 grains was greatly increased by the sprays of aphicide and fungicides and was decreased by $N$ in 1981, but not in 1980 . Largest yields of grain were $10.14 \mathrm{t} / \mathrm{ha}$ in 1980 and $10.91 \mathrm{t} / \mathrm{ha}$ in 1981 when $\mathrm{N}$ was given in spring at 160 and $200 \mathrm{~kg} / \mathrm{ha}$ respectively, and the crops were sprayed with pesticides.

In 1982 and $1983 \mathrm{~N}$ applied in March again greatly increased the number of shoots in April, but not the final number of ears. Yields of grain were larger after beans than after wheat, mainly because the number of ears and the weight of 1000 grains were greater. This may have been because take-all (Gaeumannomyces graminis var. tritici) was more severe where wheat followed wheat. Previous cropping also interacted with variety; Avalon yielded slightly less than Norman where take-all was slight but much less where take-all was severe. Where $\mathrm{N}$ was given the mean loss in yield from growing Avalon rather than Norman in the 2 years was $2.47 \mathrm{t} / \mathrm{ha}$ after wheat and $0.37 \mathrm{t} / \mathrm{ha}$ after beans. The take-all disease ratings of Norman and Avalon after wheat were 132 and 197 respectively. Yields of grain were greatly increased by $\mathrm{N}$ given during April, especially of wheat following wheat and where it was protected with sprays; then the mean yield was only $2.79 \mathrm{t} / \mathrm{ha}$ without $\mathrm{N}$ but 8.78 with $235 \mathrm{~kg} \mathrm{~N} / \mathrm{ha}$. Where wheat followed beans, yields were $6.89 \mathrm{t} / \mathrm{ha}$ without $\mathrm{N}$ and 11.07 with $175 \mathrm{~kg} \mathrm{~N} / \mathrm{ha}$. Applying $N$ to the seed bed increased yields slightly, and again by more than by dividing the dressing of $\mathrm{N}$ in spring. The number of ears was greatly increased by $\mathrm{N}$ in spring and a little by all the other factors that increased grain yield. The weight of 1000 grains was increased
\end{abstract}


greatly by the sprays of aphicide and fungicides, was decreased by $\mathrm{N}$, and was larger for Norman than for Avalon.

In 1980-1, after beans, the mean amounts of $\mathrm{N}$ removed by the grain (where aphicide and fungicides were given) ranged from $81 \mathrm{~kg} / \mathrm{ha}$ without $\mathrm{N}$ fertilizer to 167 where most $\mathrm{N}$ was given. In $1982-3$ comparable values ranged from $86 \mathrm{~kg} \mathrm{~N} / \mathrm{ha}$ to 191 where wheat followed beans and from $35 \mathrm{~kg} \mathrm{~N} / \mathrm{ha}$ to 163 where wheat followed wheat.

\section{INTRODUCTION}

Yields of winter wheat on the sandy clay loam (Beccles Series) at Saxmundham in the 1960s and early 1970 s were often much smaller than those on silty clay loams at Rothamsted. Widdowson, Johnston \& Penny (1980) discussed the problems in the introduction to an earlier paper. During 1971-6 they tested numerous agronomic factors on continuous winter wheat. The results showed little loss of yield from take-all (Gaeumannomyces graminis var. tritici) though before 1971 yields had been larger in the year following a 2-year break than where wheat followed wheat (Slope, Etheridge \& Williams, 1973). The possibility that there were physiological restraints to yields at Saxmundham was examined by measuring both root development and top growth on comparable crops at the two stations. However, the general patterns of root distribution and the growth of stems and foliage were similar on the two soils, and where the same variety was grown continuously yields were remarkably alike, showing that the two soils had similar capabilities (Widdowson et al. 1980).

After 1976 the site at Saxmundham was used for a series of spring barley experiments (Widdowson, Jenkyn \& Penny, 1982), and attempts were made to enhance the yield of winter wheat with consecutive sprays of fungicides and liquid $\mathrm{N}$-fertilizer on another part of the field (Penny, Widdowson \& Jenkyn, 1983). The fungicides and the liquid $\mathrm{N}$. fertilizer did not always increase yield when applied separately, but they did when applied together, apparently by increasing the weight of 1000 grains. Though yields were enhanced by these treetments the main benefit was in grain nitrogen content which was increased from 1.80 to $1.98 \% \mathrm{~N}$ in dry matter.

Widdowson et al. (1980) showed that the change from Cappelle-Desprez to Maris Huntsman, where wheat was grown continuously, enhanced yields only a little. Later experiments confirmed this, but showed that when wheat followed beans, Maris Huntsman yielded more than Cappelle-Desprez (Penny et al. 1983). Increased yields from the new wheat varieties were apparently more dependent on the use of break-crops than those from CappelleDesprez had been in the earlier experiments at Saxmundham. Accordingly we decided to grow winter beans each year and to follow them with winter wheat and then barley, so that the wheat was grown under the best possible conditions.
The first multifactorial experiment on winter wheat after beans was sown in September 1979 and repeated with modifications for three more years. We anticipated that the yield potential was likely to be large, because losses from foot and root rots would be minimal after the break crop. Also, by sowing in late September instead of mid-October we hoped to encourage growth during the autumn when the soil would be rich in $\mathrm{N}$ after beans. We also sought to determine optimum fertilizer $\mathrm{N}$, in terms both of timing and of the total amount needed, and whether or not this differed in the presence and absence of sprays applied to limit losses from pests and diseases. All of these tests were made on a semi-dwarf, stiff-strawed, winter wheat variety (Virtue) then being made available by the Plant Breeding Institute at Cambridge. This followed the successful use of the variety Hustler at Rothamsted where yields in excess of $10 \mathrm{t} / \mathrm{ha}$ were obtained, provided that the wheat was sown in September, was given adequate $\mathrm{N}$ in spring and that losses from leaf diseases and aphids were minimized by using appropriate sprays (Prew et al. 1983). Subsequently we compared the nitrogen requirement of a bread-making wheat (Avalon) with that of a feeding wheat (Virtue in 1981 and Norman in 1982 and 1983). After 1981, we grew two successive crops of winter wheat and repeated the tests on the same plots, to compare the nitrogen requirement of the first and second crops of wheat after beans.

\section{EXPERIMENTAL DETAILS}

\section{Sites and soil}

Two sites on the same field were used (the Intensive Wheat site, and Grove Plot). The soil on both sites is a sandy clay of the Beccles Series (Hodge, 1972), typical of the heavy land in that area and formed in Chalky Boulder Clay with the surface layers containing much sand. The former site was used during 1966-70 for a comparison of continuous winter wheat with wheat grown after a 2-year break of Italian ryegrass and beans (Slope et al. 1973). It was then used for multifactorial experiments on continuous winter wheat during 1971-6 (Widdowson et al. 1980), on spring barley during 1977-8 (Widdowson et al. 1982) and on winter barley during 1979-80 (Widdowson, Jenkyn \& Penny, 1980, 1981). Grove Plot had previously been used for annual experiments, mainly with 
Table 1. The sequence of autumn-sown crops on Grove Plot and on the Intensive Wheat site during 1979-83

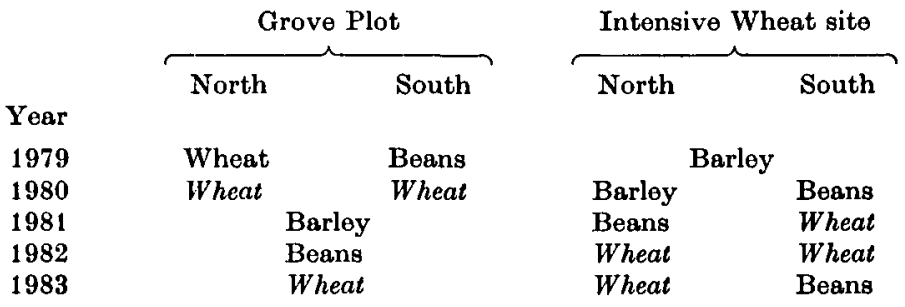

Experimental treatments were applied to crops in italic type.

Table 2. Calendar of operations

\begin{tabular}{|c|c|c|c|c|}
\hline & $1979-80$ & $1980-1$ & $1981-2$ & $1982-3$ \\
\hline \multicolumn{5}{|c|}{ Seed sown and seed-bed $N$ applied } \\
\hline September & 26. ix & 29. ix & - & 29. ix \\
\hline October & 16. $x$ & - & 13. $x$ & - \\
\hline \multicolumn{5}{|l|}{$\begin{array}{l}\text { Spring N applied } \\
\text { Divided dressings }\end{array}$} \\
\hline 1 st & 12. ii & 19. ii & 24. iii & 8. iii \\
\hline 2nd & 31. iii & 14. iv & 21. iv & 27. iv \\
\hline Single dressings & 31. iii & 14. iv & 21. iv & 27. iv \\
\hline \multicolumn{5}{|c|}{ Pathogen and aphid control applied } \\
\hline 1st & 10. iv & 14. iv & 1. iv & 4. $v$ \\
\hline 2nd & 14. $v$ & $20 . \mathrm{v}$ & 26. v & 25. v \\
\hline 3 rd & 18. vi & 2. vii & 30. vi & 22. vi \\
\hline 4th & 8. vii & - & - & - \\
\hline
\end{tabular}

cereals. Table 1 shows the subsequent cropping sequences on the two sites.

\section{Treatments and design}

In 1980 we tested three factors, each at two levels $\left(2^{3}\right):(1)$ sowing date (September $v$. October), (2) $\mathrm{N}$ to seed bed (none $v .50 \mathrm{~kg} \mathrm{~N} / \mathrm{ha}$ ) and (3) aphid and pathogen control (none $v$. sprays of aphicide and fungicides). Each whole plot was split into four subplots to test $0,80,120$ and $160 \mathrm{~kg} \mathrm{~N} /$ ha applied as either single or divided dressings in spring (Tables 2 and 3 ); there were thus 32 subplots. The nitrogen tests were arranged in a half-replicate design, both after wheat and after beans.

In 1981, the factors tested on the eight whole plots were (1) two varieties (Avalon $v$. Virtue), (2) without and with seed-bed $N$ and (3) without and with aphicide and fungicides $\left(2^{3}\right)$. Each whole plot was split into five subplots to compare $0,80,120$, 160 and $200 \mathrm{~kg} \mathrm{~N} / \mathrm{ha}$; the nitrogen was applied as either a single or divided dressing in spring. These $\mathbf{N}$ tests were again arranged in a halfreplicate design of 32 subplots $\left(4 \times 2^{3}\right)$, which together with those not given $\mathrm{N}$ in spring made a total of 40 .
In 1982, the same design was used as in 1981, both where wheat followed beans and where it followed wheat, but the variety Norman replaced Virtue; all the other treatments were repeated on the same plots where wheat followed wheat. Amounts of $\mathrm{N}$ tested were $0,70,100,130$ and $160 \mathrm{~kg} / \mathrm{ha}$ after beans and $0,130,160,190$ and $220 \mathrm{~kg} / \mathrm{ha}$ after wheat.

In 1983, the design and varieties were the same as in 1982. The amounts of $\mathrm{N}$ tested in spring were $0,100,130,160$ and $190 \mathrm{~kg} / \mathrm{ha}$ after beans and 0 , $160,190,220$ and $250 \mathrm{~kg} / \mathrm{ha}$ after wheat. The amounts of $\mathrm{N}$ tested differed because the amounts of $\mathrm{NO}_{3}-\mathrm{N}$ in the soils in autumn were larger in 1981 than in 1982 and larger after beans than after wheat.

\section{Method}

Basal $\mathbf{P}$ and $\mathrm{K}$ fertilizer was broadcast over the stubble of the previous crop; the sites were then ploughed and a seed bed prepared. The seeds were sown at $400 / \mathrm{m}^{2}$ in rows $15 \mathrm{~cm}$ apart. In autumn 1979,1980 and 1981 seed-bed $N$ was tested by broadcasting fertilizers containing either $20 \% \mathrm{P}_{2} \mathrm{O}_{5}$ and $\mathrm{K}_{2} \mathrm{O}$, or $15 \% \mathrm{~N}, 15 \% \mathrm{P}_{2} \mathrm{O}_{5}$ and $15 \% \mathrm{~K}_{2} \mathrm{O}$ to 
Table 3. Details of aphid and pathogen control

\begin{tabular}{|c|c|}
\hline \multicolumn{2}{|c|}{1980} \\
\hline Date & $\begin{array}{l}\text { Product } \\
\text { number }\end{array}$ \\
\hline 10. iv & 3 \\
\hline 14. $\mathrm{v}$ & 5,7 \\
\hline 18. vi & $1,5,7$ \\
\hline 8. viii & $1,6,7$ \\
\hline
\end{tabular}

Product
number

1

2

3

4

5

6

7

8
1981

$\begin{array}{ll}\text { Date } & \begin{array}{l}\text { Product } \\ \text { number }\end{array} \\ \text { 14. iv } & 2,4 \\ \text { 20. v } & 1,5,7 \\ 2 . \text { vii } & 1,6,7\end{array}$

Product

Aphicide

'Aphox'

Fungicides

'Bavistin'

'Benlate'

'Calixin'

'Cosmic'

'Delsene M'

'Sanspor'

'Tilt'
1982

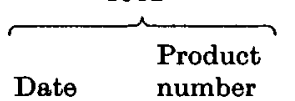

1. iv 3

26. $v$

3

1,8

30. vi

$1,5,7$
1983

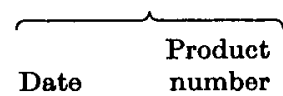

4. $v \quad 3$

25. $v$

22. vi $1,5,7$

Amount (kg/ha) of active ingredient

Pirimicarb $\quad 0 \cdot 14$
O

$\begin{array}{ll}\text { Carbendazim } & \mathbf{0 . 2 5} \\ \text { Benomyl } & \mathbf{0 . 2 8} \\ \text { Tridemorph } & 0.53 \\ \text { \{arbendazim } & \mathbf{0 \cdot 1 5} \\ \text { Maneb } & \mathbf{1} \cdot 60 \\ \text { Tridemorph } & 0 \cdot 37 \\ \text { \{arbendazim } & 0 \cdot 25 \\ \text { Maneb } & \mathbf{1 . 6 0} \\ \text { Captafol } & \mathbf{1} \cdot 10 \\ \text { Propiconazole } & 0 \cdot 12\end{array}$

supply $50 \mathrm{~kg} / \mathrm{ha}$ of $\mathrm{N}, \mathrm{P}_{2} \mathrm{O}_{5}$ and $\mathrm{K}_{2} \mathrm{O}$. In autumn 1982 basal $P$ and $K$ fertilizer was broadcast over the previous stubble only and 'Nitro-Chalk' was broadcast at sowing to supply $40 \mathrm{~kg} \mathrm{~N} / \mathrm{ha}$ where appropriate. Basal herbicides were sprayed in the autumn to control grass and broad-leaved weeds and in the spring to control any remaining weeds. In 1982 an insecticide was included with the autumn herbicide to minimize the spread of barley yellow dwarf virus by controlling aphid vectors.

'Nitro-Chalk' was broadcast by hand in spring. Divided dressings always supplied $40 \mathrm{~kg} \mathrm{~N} / \mathrm{ha}$ at the first application and the remainder at the second. Single dressings were applied on the same day as the second part of the divided dressings (Table 2). A motorized knapsack sprayer was used to apply the aphicide and fungicides (Table 3). The first application was made mainly to control the eyespot fungus, Pseudocercosporella herpotrichoides, the remainder to control foliar diseases and aphids.

In 1980 whole plots were $7.2 \mathrm{~m}$ (48 rows at $15 \mathrm{~cm}) \times 11$ m and subplots $7.2 \times 2.75 \mathrm{~m}$. Corresponding whole and subplot sizes in 1981 and 1982 were $8.4 \mathrm{~m}$ (56 rows) $\times 18.25 \mathrm{~m}$ and $8.4 \times 3.65 \mathrm{~m}$. In 1983 plot sizes on the Intensive Wheat site were the same as those in 1981 and 1982; on Grove Plot whole plots were $6.3 \times 30 \mathrm{~m}$ and subplots $6.3 \times 6 \mathrm{~m}$.

Dry weight and $\mathrm{N}$ content of green whert and numbers of plants and shoots were measured each spring on selected plots, and dry weight, $\mathrm{N}$ content and numbers of ears in July in 1982 and 1983 on all plots. An area 10 rows $\times 0.5 \mathrm{~m}$ was sampled on each occasion. In spring the plants were dug up, washed and subsampled for take-all assessment and chemical analysis; in July the crop was cut close to the ground level. In July 1980 and 1981 the number of ears was counted in two areas, each $0.1 \mathrm{~m}^{2}$, on each plot. At harvest a central cut ( $1.5 \mathrm{~m}$ wide) was combine-harvested along each subplot (across the rows). Each year yields of grain on each plot were recorded, but those of straw only after beans. Samples of grain and straw were taken to determine percentage of dry matter and $\mathrm{N}$ in the dry matter.

In 1982 and 1983 when two varieties were grown, each as the first or second wheat after beans, estimates of take-all were made in spring by counting the number of infected roots. In June at growth stage 69 (Zadoks, Chang \& Konzak, 1974) the proportion of roots infected was estimated again and graded slight (up to $25 \%$ roots infected), moderate $(25-75 \%)$ and severe (more than $75 \%$ ). From this a take-all rating was calculated: percentage slight $+(2 \times$ percentage moderate $)+(3 \times$ percentage severe); maximum rating 300. Eyespot was assessed by counting the number of infected straws in June.

In 1983 , soil cores were taken in the autumn and used to measure the take-all infectivity of soils after the first and second crops of wheat and after the beans. Five cores, each $5 \mathrm{~cm}$ diameter $\times 10 \mathrm{~cm}$ deep, were taken from the plots not given $\mathrm{N}$ and from those given the second largest amount in 
Table 4. Mean numbers of plants and shoots, yields of dry matter, percentages of $N$ and amounts of $N$ taken up in spring in 1980 and 1981

\begin{tabular}{|c|c|c|c|c|c|}
\hline & $\begin{array}{c}\text { No. of } \\
\text { plants } / \mathrm{m}^{2}\end{array}$ & $\begin{array}{c}\text { No. of } \\
\text { shoots } / \mathrm{m}^{2}\end{array}$ & $\begin{array}{l}\text { Yield }\left(\mathrm{g} / \mathrm{m}^{2}\right) \\
\text { of dry matter }\end{array}$ & $\begin{array}{l}\mathrm{N} \text { in dry } \\
\text { matter }(\%)\end{array}$ & $\begin{array}{c}\mathrm{N}(\mathrm{kg} / \mathrm{ha}) \\
\text { taken up }\end{array}$ \\
\hline \multicolumn{6}{|c|}{ Crop sampled 25. iii. 80} \\
\hline \multicolumn{6}{|c|}{ Previous crop } \\
\hline Beans & 226 & 976 & 70 & $3 \cdot 74$ & $25 \cdot 8$ \\
\hline Wheat & 232 & 915 & 65 & $3 \cdot 82$ & $25 \cdot 6$ \\
\hline \multicolumn{6}{|l|}{ Sowing date } \\
\hline 26. ix. 79 & 195 & 950 & 76 & $3 \cdot 86$ & $29 \cdot 7$ \\
\hline 16. x. 79 & 262 & 942 & 58 & $3 \cdot 69$ & $21 \cdot 7$ \\
\hline \multicolumn{6}{|c|}{$40 \mathrm{~kg} \mathrm{~N} / \mathrm{ha}$ on $12 . \mathrm{ii}$} \\
\hline Without & 218 & 853 & 59 & $3 \cdot 78$ & $22 \cdot 4$ \\
\hline With & 240 & 1038 & 76 & $3 \cdot 78$ & $29 \cdot 0$ \\
\hline \multirow[t]{2}{*}{ S.E. } & $15 \cdot 2$ & $69 \cdot 2$ & $8 \cdot 3$ & 0.247 & 4.21 \\
\hline & \multicolumn{5}{|c|}{ Crop sampled 7. iv. 81} \\
\hline Variety & & & & & \\
\hline Avalon & 238 & 1085 & 126 & $3 \cdot 24$ & $41 \cdot 2$ \\
\hline Virtue & 202 & 1073 & 113 & $3 \cdot 02$ & $34 \cdot 2$ \\
\hline \multicolumn{6}{|c|}{$50 \mathrm{~kg} \mathrm{~N} / \mathrm{ha}$ in seed bed } \\
\hline Without & 234 & 1071 & 120 & $2 \cdot 89$ & $\mathbf{3 4 \cdot 9}$ \\
\hline With & 206 & 1087 & 118 & $\mathbf{3 \cdot 3 7}$ & $40 \cdot 6$ \\
\hline \multicolumn{6}{|c|}{$40 \mathrm{~kg} \mathrm{~N} / \mathrm{ha}$ on $19 . \mathrm{ii}$} \\
\hline Without & 223 & 1040 & 110 & $2 \cdot 81$ & $30 \cdot 8$ \\
\hline With & 218 & 1118 & 129 & $3 \cdot 45$ & $44 \cdot 6$ \\
\hline S.E. & 10.9 & $101 \cdot 2$ & $3 \cdot 9$ & 0.229 & $3 \cdot 46$ \\
\hline
\end{tabular}

spring. These then were used in the bioassay method described by Slope et al. (1979). Each soil core surface was sown with eight wheat seeds (variety Flanders) and after 5 weeks five of the plants were examined and the number of plants and the number of the first five seminal roots (main axis only) infected with take-all were recorded.

\section{RESULTS}

\section{The 1980 and 1981 experiments}

\section{Growth and nitrogen uptakes in spring}

Table 4 shows that in March 1980 there were more shoots $/ \mathrm{m}^{2}$ where the wheat followed beans than where it followed wheat $(976 v .915)$ but that the yields of dry matter differed only slightly and the uptakes of $\mathbf{N}$ were the same. Dry weather delayed germination of the September-sown wheat so that it emerged only a little before the October sow. ing, but in March both yield $\left(76 v .58 \mathrm{~g} / \mathrm{m}^{2}\right)$ and uptake of $\mathrm{N}(30 \mathrm{v} .22 \mathrm{~kg} / \mathrm{ha})$ were larger with the earlier sowing. By $25 \mathrm{March} 40 \mathrm{~kg} \mathrm{~N} /$ ha (first part of the divided $\mathbf{N}$ dressing) applied 6 weeks earlier had significantly increased the number of shoots, the dry weight and the uptake of $\mathrm{N}$.

Table 4 also shows that in April 1981 there were more plants $/ \mathrm{m}^{2}$ of the variety Avalon (238) than of
Virtue (202). Although there were similar numbers of shoots of the two varieties, Avalon gave the larger dry weight, $\% \mathrm{~N}$ and $\mathrm{N}$ uptake. Forty $\mathrm{kg}$ $\mathrm{N} /$ ha, applied 7 weeks previously, again significantly increased the number of shoots, the dry weight and uptake of $\mathrm{N}$.

\section{Yields of grain and the components of yield}

In 1980. Table 5 gives mean yields with each of the factors. Of those tested at 2 levels, the aphicide plus fungicides had the largest effect $(+1 \cdot 06 \mathrm{t} / \mathrm{ha})$. The mean benefit from the preceding crop of winter beans was $0.69 \mathrm{t} / \mathrm{ha}$, which was about the same as that from applying $50 \mathrm{~kg} \mathrm{~N} / \mathrm{ha}$ in the seed bed. However, the benefit from seed-bed $\mathrm{N}$ decreased as the amount of $\mathrm{N}$ applied in spring was increased, so that it became negligible with $160 \mathrm{~kg} \mathrm{~N} / \mathrm{ha}$, after both preceding crops (Table 7). Mean increases in yield from spring-applied $\mathrm{N}$ ranged from $2.43 \mathrm{t} / \mathrm{ha}$ from the first $80 \mathrm{~kg} / \mathrm{ha}$ to $0.57 \mathrm{t}$ from the final $40 \mathrm{~kg} / \mathrm{ha}$, so $160 \mathrm{~kg} \mathrm{~N} / \mathrm{ha}$ was perhaps not enough to give maximum yield. Neither sowing date nor division of $\mathrm{N}$ in spring much affected yield (Table 5). Yields were always larger where wheat followed beans if all other treatments were the same (Table 7).

Because aphicide plus fungicides and $\mathrm{N}$ rates in 
Table 5. Mean yields, percentages of $N$ in, and amounts of $N$ taken up by wheat grain, together with numbers of ears and weights of 1000 dry grains in 1980

\begin{tabular}{|c|c|c|c|c|c|}
\hline Whole-plot treatments & $\begin{array}{c}\text { Yield (t/ha) at } \\
85 \% \text { D.M. }\end{array}$ & $\begin{array}{c}N \text { in grain } \\
(\%)\end{array}$ & $\begin{array}{l}\mathrm{N}(\mathrm{kg} / \mathrm{ha}) \\
\text { taken up }\end{array}$ & $\begin{array}{c}\text { No. of } \\
\text { ears } / \mathrm{m}^{8}\end{array}$ & $\begin{array}{l}\text { Weight }(\mathrm{g}) \text { of } \\
1000 \text { dry grains }\end{array}$ \\
\hline \multicolumn{6}{|l|}{ Previous crop } \\
\hline Beans & $8 \cdot 29$ & $1 \cdot 68$ & $120 \cdot 7$ & 506 & $46 \cdot 1$ \\
\hline Wheat & $\mathbf{7 \cdot 6 0}$ & 1.67 & $109 \cdot 1$ & 473 & $45 \cdot 1$ \\
\hline \multicolumn{6}{|l|}{ Sowing date } \\
\hline 26. ix. 79 & 8.00 & $1 \cdot 69$ & $116 \cdot 7$ & 476 & $46 \cdot 2$ \\
\hline 16. x. 79 & $7 \cdot 89$ & $1 \cdot 66$ & $113 \cdot 0$ & 504 & $\mathbf{4 5} \cdot 0$ \\
\hline \multicolumn{6}{|c|}{$50 \mathrm{~kg} \mathrm{~N} / \mathrm{ha}$ in seed bed } \\
\hline Without & 7.59 & $1 \cdot 64$ & $107 \cdot 5$ & 476 & $45 \cdot 7$ \\
\hline With & $8 \cdot 30$ & $1 \cdot 71$ & $122 \cdot 3$ & 504 & $45 \cdot 4$ \\
\hline \multicolumn{6}{|c|}{ Aphicide and fungicides } \\
\hline Without & $7 \cdot 42$ & 1.68 & $107 \cdot 6$ & 483 & $43 \cdot 5$ \\
\hline With & 8.48 & $1 \cdot 67$ & $122 \cdot 1$ & 497 & $47 \cdot 7$ \\
\hline s.e. & $0 \cdot 059$ & 0.023 & 1.74 & $6 \cdot 1$ & $0 \cdot 18$ \\
\hline \multicolumn{6}{|c|}{$\begin{array}{l}\text { Subplot treatments } \\
\mathbf{N} \text { dressing in spring }\end{array}$} \\
\hline Divided & 7.92 & $1 \cdot 66$ & $113 \cdot 3$ & 496 & $45 \cdot 2$ \\
\hline Single & 7.98 & 1.69 & $116 \cdot 5$ & 484 & $46 \cdot 0$ \\
\hline S.E. & $0 \cdot 056$ & 0.009 & 0.95 & 7.5 & $0 \cdot 14$ \\
\hline \multicolumn{6}{|c|}{$\mathrm{N}(\mathrm{kg} / \mathrm{ha})$ in spring } \\
\hline 0 & $5 \cdot 68$ & $1 \cdot 48$ & $71 \cdot 5$ & 408 & $45 \cdot 1$ \\
\hline 80 & $8 \cdot 11$ & 1.62 & $111 \cdot 9$ & 494 & $45 \cdot 6$ \\
\hline 120 & $8 \cdot 72$ & 1.72 & $128 \cdot 0$ & 514 & $45 \cdot 8$ \\
\hline 160 & $9 \cdot 29$ & $1 \cdot 88$ & $148 \cdot 0$ & 543 & $45 \cdot 7$ \\
\hline S.E. & 0.079 & 0.013 & $1 \cdot 35$ & $10 \cdot 6$ & 0.20 \\
\hline
\end{tabular}

spring interacted, yields and other data from the combination of these two factors are given in detail in Appendix Tables. Appendix Table 1 shows that best yields of grain after beans were $9.00 \mathrm{t} / \mathrm{ha}$ without aphicide and fungicides but $10 \cdot 14$ with them, and after wheat $8 \cdot 36$ and 9.65 respectively. After beans the effect of aphicide plus fungicides on yield varied inconsistently with $\mathrm{N}$ rate, but after wheat they increased yield by approximately $1 \mathrm{t} / \mathrm{ha}$ in the absence of $\mathrm{N}$ and by $1.3 \mathrm{t} / \mathrm{ha}$ in the presence of each amount of $\mathrm{N}$; their mean effects were $0.90 \mathrm{t} / \mathrm{ha}$ after beans and $1.22 \mathrm{t} / \mathrm{ha}$ after wheat.

As the eyespot fungus can survive a 1-year break from cereals the first spray of fungicide (Tables 2 and 3) was intended mainly for the control of this pathogen. Appendix Table 1 shows that the fungicides increased the numbers of ear-bearing stems where the wheat followed wheat, but not where it followed beans. The sprays also increased the numbers of grains $/ \mathrm{m}^{2}$, mostly by increasing numbers of ears. The weight of 1000 dry grains was greatly increased by the aphicide and fungicides (Table 5) and this effect was consistent after both previous crops, so that it accounted for much of the increase in yield from the sprays (Appendix Table 1).

Table 5 shows that the mean weight of 1000 grains was increased by growing beans instead of wheat as the preceding crop. After beans there were more shoots in spring and even though only half of them survived to bear ears there were still more than after wheat. Previous crop did not influence the number of fertile spikelets, so the number of grains $/ \mathrm{m}^{2}$ was a reflexion of the number of ears (Appendix Table 1).

$\mathrm{N}$ rates in spring had little influence on the weight of 1000 grains and the increased yields again came from a larger number of ears and grains $/ \mathrm{m}^{2}$ (Table 5 and Appendix Table 1).

In 1981 . Wheat was grown only after beans and Table 6 gives mean yields from each factor tested. Aphicide plus fungicides had a large effect $(+1.83$ $t / h a)$, double that on a comparable crop in 1980 . Table 7 shows that $\mathrm{N}$ applied in the seed bed again had a large effect $(0.71 \mathrm{t} / \mathrm{ha})$ when $\mathrm{N}$ was not given in spring but a much smaller effect when it was. In 1981, and subsequently, nil $\mathrm{N}$ treatments in spring were on extra plots and not in the factorial design 
Table 6. Mean yields, percentages of $N$ in, and amounts of $N$ taken up by wheat grain, together with numbers of ears and weights of 1000 dry grains in 1981

\begin{tabular}{|c|c|c|c|c|c|}
\hline Whole-plot treatments & $\begin{array}{c}\text { Yield (t/ha) at } \\
85 \% \text { D.M. }\end{array}$ & $\begin{array}{c}N \text { in grain } \\
(\%)\end{array}$ & $\begin{array}{l}\mathrm{N}(\mathrm{kg} / \mathrm{ha}) \\
\text { taken up }\end{array}$ & $\begin{array}{c}\text { No. of } \\
\text { ears } / \mathrm{m}^{2}\end{array}$ & $\begin{array}{l}\text { Weight }(g) \text { of } \\
1000 \text { dry graing }\end{array}$ \\
\hline $\begin{array}{l}\text { Variety } \\
\text { Avalon } \\
\text { Virtue }\end{array}$ & $\begin{array}{l}9 \cdot 34 \\
9 \cdot 43\end{array}$ & $\begin{array}{l}1.84 \\
1.68\end{array}$ & $\begin{array}{l}146 \cdot 1 \\
134 \cdot 5\end{array}$ & $\begin{array}{l}464 \\
594\end{array}$ & $\begin{array}{l}42 \cdot 0 \\
39 \cdot 9\end{array}$ \\
\hline $\begin{array}{l}50 \mathrm{~kg} \mathrm{~N} / \mathrm{ha} \text { in } \mathrm{se} \\
\text { Without } \\
\text { With }\end{array}$ & $\begin{array}{r}9 \cdot 29 \\
9 \cdot 48\end{array}$ & $\begin{array}{l}1 \cdot 71 \\
1.81\end{array}$ & $\begin{array}{l}135 \cdot 4 \\
145 \cdot 2\end{array}$ & $\begin{array}{l}530 \\
628\end{array}$ & $\begin{array}{l}40 \cdot 6 \\
41 \cdot 2\end{array}$ \\
\hline $\begin{array}{l}\text { Aphicide and fu } \\
\text { Without } \\
\text { With } \\
\text { S.E. }\end{array}$ & $\begin{array}{l}\text { gicides } \\
\qquad \begin{array}{c}8.47 \\
10 \cdot 30 \\
0.056\end{array}\end{array}$ & $\begin{array}{l}1.82 \\
1.70 \\
0.013\end{array}$ & $\begin{array}{r}131 \cdot 4 \\
149 \cdot 2 \\
1.67\end{array}$ & $\begin{array}{l}519 \\
639 \\
11 \cdot 5\end{array}$ & $\begin{array}{l}37 \cdot 6 \\
44 \cdot 3 \\
0 \cdot 18\end{array}$ \\
\hline $\begin{array}{l}\text { Subplot treatments } \\
\mathrm{N} \text { dressing in sp } \\
\text { Divided } \\
\text { Single }\end{array}$ & $\begin{array}{l}9 \cdot 40 \\
9 \cdot 37\end{array}$ & $\begin{array}{l}1.72 \\
1.80\end{array}$ & $\begin{array}{l}137 \cdot 5 \\
143 \cdot 1\end{array}$ & $\begin{array}{l}541 \\
517\end{array}$ & $\begin{array}{l}41 \cdot 2 \\
40 \cdot 6\end{array}$ \\
\hline S.E. & 0.056 & 0.013 & 1.67 & 11.5 & $0 \cdot 18$ \\
\hline $\begin{array}{c}N(\mathrm{~kg} / \mathrm{ha}) \text { in spr } \\
0 \\
80 \\
120 \\
160 \\
200\end{array}$ & $\begin{array}{l}6 \cdot 65 \\
8 \cdot 79 \\
9 \cdot 38 \\
9 \cdot 66 \\
9 \cdot 71\end{array}$ & $\begin{array}{l}1 \cdot 48 \\
1 \cdot 58 \\
1 \cdot 69 \\
1 \cdot 84 \\
1.92\end{array}$ & \begin{tabular}{r|}
$83 \cdot 4$ \\
$118 \cdot 1$ \\
$134 \cdot 8$ \\
$151 \cdot 0$ \\
$157 \cdot 3$
\end{tabular} & $\begin{array}{l}386 \\
501 \\
520 \\
523 \\
573\end{array}$ & $\begin{array}{l}44 \cdot 0 \\
42 \cdot 3 \\
41 \cdot 2 \\
40 \cdot 8 \\
39 \cdot 5\end{array}$ \\
\hline S.E. & $0 \cdot 079$ & 0.018 & $2 \cdot 37$ & $16 \cdot 3$ & 0.25 \\
\hline
\end{tabular}

and so are excluded from the main comparisons. Although Table 6 shows that mean yields of the two varieties differed little, they varied considerably when given the aphicide plus fungicides sprays; thus yields from Avalon and Virtue were 8.89 and 8.04 t/ha respectively without, but 9.78 and 10.82 with the sprays, confirming the greater susceptibility of the variety Virtue to foliar diseases (National Institute of Agricultural Botany, 1981). Table 6 shows that $160 \mathrm{~kg} \mathrm{~N} / \mathrm{ha}$ in spring was almost enough, but where aphicide plus fungicides were given $200 \mathrm{~kg} \mathrm{~N} / \mathrm{ha}$ was justified and the maximum yield was $10.91 \mathrm{t} / \mathrm{ha}$ (Appendix Table 2). The effect of aphicide plus fungicides ranged from $-0.11 \mathrm{t} / \mathrm{h}$ a without $\mathrm{N}$ in spring to $+2.40 \mathrm{t} / \mathrm{ha}$ with $200 \mathrm{~kg} \mathrm{~N} / \mathrm{ha}$, so that the interaction between $\mathrm{N}$ and the aphicide plus fungicides treatment was much more pronounced than in 1980. Division of $\mathbf{N}$ in spring was not important.

The small mean increase in the number of ears from applying aphicide plus fungicides (Table 6) came mostly from wheat not given $N$ in spring (Appendix Table 2). Table 6 shows that the main cause of the increased yield from a phicide plus fungicides was the larger weight of 1000 grains and this benefit from the sprays increased as more $\mathrm{N}$ was applied (Appendix Table 2). The variety Virtue had many more ears than Avalon, but this was counteracted by a smaller 1000-grain weight, so mean yields differed little.

\section{Nitrogen contents of grain}

In 1980. Table 5 shows that $\% \mathrm{~N}$ in the grain was little increased by $\mathrm{N}$ applied in the seed bed, but markedly by $\mathrm{N}$ applied in spring. Uptake of $\mathrm{N}$, however, was increased not only by these two factors but also by the preceding crop of beans and by the aphicide plus fungicides sprays. The uptake of $\mathrm{N}$ was doublod by applying the largest amount of $\mathrm{N}$ in spring, both after beans and after wheat (Appendix Table 1).

In 1981. Table 6 shows that, apart from $\mathrm{N}$ rates in spring, \% $\mathrm{N}$ in the grain was influenced most by variety, being larger in the milling wheat (Avalon) than in the feeding wheat (Virtue). Seed-bed N, and spring $\mathbf{N}$ applied as a single instead of a divided dressing, increased $\% \mathrm{~N}$ a little. The uptake of $\mathrm{N}$ was almost doubled by applying $200 \mathrm{~kg} \mathrm{~N} / \mathrm{ha}$ in spring; it was also significantly increased, in descending order of magnitude, by aphicide plus fungicides, by growing Avalon instead of Virtue, by giving $N$ in the seed bed and by applying $N$ in a single rather than a divided dose in spring (Table 6). The effect of aphicide plus fungicides on uptake 
Table 7. Mean yields ( $t / h a$ ) of grain ( $85 \%$ D.M.) given by $N$ applied in the seed bed in the presence of increasing amounts of $N$ applied in spring, in 1980 and 1981

\begin{tabular}{|c|c|c|c|c|c|}
\hline \multirow{2}{*}{$\begin{array}{l}N(\mathrm{~kg} / \mathrm{ha}) \\
\text { in seed bed }\end{array}$} & \multicolumn{5}{|c|}{$\mathrm{N}(\mathrm{kg} / \mathrm{ha})$ in spring } \\
\hline & 0 & 80 & 120 & 160 & 200 \\
\hline \multicolumn{6}{|c|}{ Mean yields (t/ha): 1980} \\
\hline \multicolumn{6}{|c|}{ Wheat after beans } \\
\hline 0 & $\mathbf{5 . 5 7}$ & $8 \cdot 13$ & 8.55 & 9.54 & - \\
\hline 50 & $6 \cdot 69$ & $8 \cdot 89$ & $\mathbf{9} \cdot \mathbf{3 8}$ & $9 \cdot 60$ & 一 \\
\hline \multicolumn{6}{|c|}{ S.E. 0.182} \\
\hline \multicolumn{6}{|c|}{ Wheat after wheat } \\
\hline 0 & $4 \cdot 59$ & $7 \cdot 25$ & $8 \cdot 15$ & 8.98 & - \\
\hline 50 & $6 \cdot 87$ & $8 \cdot 16$ & $8 \cdot 82$ & $9 \cdot 03$ & - \\
\hline \multicolumn{6}{|c|}{ S.E. $0 \cdot 170$} \\
\hline \multirow{2}{*}{\multicolumn{6}{|c|}{$\begin{array}{l}\text { Mean yields ( } t / \text { ha }): 1981 \\
\text { Wheat after beans }\end{array}$}} \\
\hline & & & & & \\
\hline $\mathbf{0}$ & $6 \cdot 29$ & $8 \cdot 49$ & $9 \cdot 26$ & $9 \cdot 58$ & $9 \cdot 82$ \\
\hline 50 & $7 \cdot 00$ & $9 \cdot 09$ & 9.50 & $9 \cdot 73$ & $9 \cdot 60$ \\
\hline
\end{tabular}

of $\mathrm{N}$ ranged from $-5 \mathrm{~kg} / \mathrm{ha}$ without $\mathrm{N}$ to $+22 \mathrm{~kg} /$ ha with $200 \mathrm{~kg} \mathrm{~N} / \mathrm{ha}$ in spring (Appendix Table 2).

\section{Yields and nitrogen contents of straw}

Appendix Tables 1 and 2 show that yields of straw in 1980 and 1981 were never more than half those of grain; they increased with increasing $\mathrm{N}$ rates, were little influenced by aphicide plus fungicides in 1980 , but were consistently increased by them in 1981. The amount of $\mathrm{N}$ given in spring influenced percentages and uptakes of $\mathrm{N}$ in straw similarly to those in grain. Aphicide plus fungicides had little effect on percentages of $N$ in 1980 , but decreased them consistently in 1981 , so much so that they also decreased uptakes of $N$, even though they increased yields.

\section{The 1982 and 1983 experiments}

In 1982 and 1983 the experiments were made on first and second wheat crops after beans; treatments were cumulative for wheat after wheat.

\section{Growth and nitrogen uptakes in spring}

Table 8 shows that the previous crop had no effect, in either year, on the number of plants surviving over winter, but that the number of shoots, dry weight and nitrogen uptake were all larger after beans. Variety had little effect on any of these measurements except that the number of shoots was larger for Norman than for Avalon in both years. Applying nitrogen in the seed bed appreciably increased the number of plants in April in both years, but otherwise had little effect on number of shoots, dry weight or $\mathrm{N}$ uptake relative to that from the beans. Giving $40 \mathrm{~kg} \mathrm{~N} / \mathrm{ha}$ during March increased the number of shoots, especially in 1983 , and both dry weight and $\mathrm{N}$ uptake each year.

\section{Foot and root rots}

In 1982 and 1983, the crop samples taken in spring were used for take-all assessments. On wheat following wheat there was then little difference between the varieties; thus in $1982,50 \%$ of plants of Avalon and $44 \%$ of plants of Norman were infected with take-all and in 1983,57 and $54 \%$ respectively. By June each year obvious take-all patches were showing on the second wheat crop after beans but not on the first. In 1982, take-all patches were more apparent in Avalon than in Norman (30 and 10\% of crop affected respectively) and in 1983, although less obvious, this occurred again (10\% in Avalon, $2 \%$ in Norman). Assessments of take-all, made on the samples of plants taken in June, confirmed these visual differences between the varieties and between the years (Table 9). Also, take-all was more severe on wheat grown without than with nitrogen fertilizer (Fig. 3). In contrast to the second crop of wheat, take-all was scarce on the first after beans, with little difference between the varieties (Table 9).

The infectivity of soils in autumn 1983, measured by the wheat seedling bioassay, showed that the 
Table 8. Mean number of plants and shoots, yields of dry matter, percentages of $N$ and amounts of $N$ taken up in spring in 1982 and 1983

\begin{tabular}{|c|c|c|c|c|c|}
\hline & $\begin{array}{c}\text { No. of } \\
\text { plants } / \mathrm{m}^{2}\end{array}$ & $\begin{array}{c}\text { No. of } \\
\text { shoots } / \mathrm{m}^{\mathrm{a}}\end{array}$ & $\begin{array}{l}\text { Yield }\left(\mathrm{g} / \mathrm{m}^{2}\right) \\
\text { of dry matter }\end{array}$ & $\begin{array}{c}N \text { in dry } \\
\text { matter }(\%)\end{array}$ & $\begin{array}{c}\mathrm{N}(\mathrm{kg} / \mathrm{ha}) \\
\text { taken up }\end{array}$ \\
\hline \multicolumn{6}{|c|}{ Crop sampled 21. iv. 82} \\
\hline Previous or & & & & & \\
\hline Beans & 182 & 1003 & 160 & $3 \cdot 15$ & 51 \\
\hline Wheat & 180 & 793 & 106 & $2 \cdot 75$ & 29 \\
\hline \multicolumn{6}{|l|}{ Variety } \\
\hline Avalon & 188 & 860 & 135 & 2.92 & 40 \\
\hline Norman & 174 & 936 & 131 & $2 \cdot 99$ & 39 \\
\hline \multicolumn{6}{|c|}{$40 \mathrm{~kg} \mathrm{~N} / \mathrm{ha}$ on $24 . \mathrm{iii}$} \\
\hline Without & 181 & 885 & 122 & $2 \cdot 96$ & 37 \\
\hline With & 180 & 911 & 144 & $2 \cdot 95$ & 43 \\
\hline s.E. & $10 \cdot 8$ & $45 \cdot 6$ & $2 \cdot 7$ & 0.085 & $1 \cdot 0$ \\
\hline \multicolumn{6}{|c|}{ Crop sampled 27. iv. 83} \\
\hline \multicolumn{6}{|c|}{ Previous crop } \\
\hline Beans & 215 & 888 & 290 & 1.81 & 53 \\
\hline Wheat & 217 & 813 & 217 & $1 \cdot 78$ & 39 \\
\hline \multicolumn{6}{|l|}{ Variety } \\
\hline Avalon & 236 & 734 & 269 & 1.72 & 46 \\
\hline Norman & 197 & 967 & 238 & 1.88 & 45 \\
\hline \multicolumn{6}{|c|}{$40 \mathrm{~kg} \mathrm{~N} / \mathrm{ha}$ on $8 . \mathrm{iii}$} \\
\hline Without & 202 & 770 & 200 & $1 \cdot 70$ & 34 \\
\hline With & 230 & 931 & 307 & $1 \cdot 89$ & 58 \\
\hline S.E. & $16 \cdot 9$ & $30 \cdot 4$ & $11 \cdot 1$ & 0.048 & $1 \cdot 7$ \\
\hline
\end{tabular}

amount of inoculum left after the first crop of the variety Avalon was twice that left after the variety Norman (Table 10). After the second wheat crop both varieties left similar amounts of inoculum.

There was little infection of straws by sharp eyespot (Rhizoctonia cerealis Van der Hoevea) on either the first or second wheat crops in 1982 and 1983, and there was no consistent difference in susceptibility to eyespot between the two varieties (Table 11). The percentage of straws with eyespot (mean of both varieties) was similar for both years in

Table 9. Take-all (expressed as a rating) in two winter wheat varieties grown with and without $N$ fertilizers in 1982 and 1983

\begin{tabular}{lcccc} 
Previous crop ... & $\overbrace{\text { Wheat }}^{1982}$ & \multicolumn{2}{c}{1983} \\
& Mean of four nitrogen & Wheat & Beans \\
Variety & & & & \\
Avalon & 221 & 16 & 173 & 15 \\
Norman & 150 & 4 & 115 & 13 \\
& & & & \\
Avalon & Without & N fertilizer & & \\
Norman & 274 & 16 & 267 & 29 \\
& 206 & 9 & 205 & 22
\end{tabular}

wheat after wheat, but wheat after beans had less eyespot in 1982 than the corresponding crop in 1983. Applying a fungicide spray in spring to control eyespot reduced infections in June, but gener. ally the percentage reduction was more for wheat after beans than for wheat after wheat (Table 11).

Growth and nitrogen uptakes during grain filling

Appendix Table 3 shows, for the main factorial arrangement, the mean value for each factor. At this stage of crop development all the factors tested were having a significant positive effect on dry weight and on the amount of $\mathrm{N}$ taken up. However,

Table 10. The bioassay of take-all infectivity of soils taken in September 1983, from each phase of a threecourse rotation, in which the varieties Avalon and Norman were compared

Percentage of roots (variety Flanders) with take-all

$\begin{array}{llrr}\text { Variety ... } & & \text { Avalun } & \text { Norman } \\ \text { Previous crop } & & & \\ 1982 & 1983 & & \\ \text { Wheat } & \text { Beans } & 2 \cdot 6 & 2 \cdot 3 \\ \text { Beans } & \text { Wheat } & 41.9 & 20.0 \\ \text { Wheat } & \text { Wheat } & 43.6 & 45.2\end{array}$


Table 11. Percentage of straws infected with eyespot in two winter wheat varieties grown after either beans or wheat in 1982 and 1983

\begin{tabular}{|c|c|c|c|c|c|c|c|c|c|}
\hline \multirow[b]{2}{*}{ Fungicide } & \multirow[b]{2}{*}{$\cdots$} & \multicolumn{4}{|c|}{1982} & \multicolumn{4}{|c|}{1983} \\
\hline & & \multicolumn{2}{|c|}{ Without } & \multicolumn{2}{|c|}{ With } & \multicolumn{2}{|c|}{ Without } & \multicolumn{2}{|l|}{ With } \\
\hline Infection & $\cdots$ & $\begin{array}{l}\text { Moderate } \\
\text { plus severe }\end{array}$ & Total & $\begin{array}{l}\text { Moderate } \\
\text { plus severe }\end{array}$ & Total & $\begin{array}{l}\text { Moderate } \\
\text { plus severe }\end{array}$ & Total & $\begin{array}{l}\text { Moderate } \\
\text { plus severe }\end{array}$ & Total \\
\hline \multicolumn{5}{|l|}{ Variety } & \multicolumn{3}{|c|}{ Previous crop beans } & & \\
\hline Avalon & & $6 \cdot 4$ & $23 \cdot 7$ & $2 \cdot 2$ & $6 \cdot 1$ & $24 \cdot 6$ & $52 \cdot 6$ & $9 \cdot 7$ & $37 \cdot 7$ \\
\hline Norman & & $6 \cdot 6$ & $19 \cdot 1$ & $1 \cdot 8$ & $7 \cdot 5$ & $22 \cdot 4$ & $44 \cdot 0$ & 0.7 & $6 \cdot 7$ \\
\hline Mean & & $6 \cdot 5$ & $11 \cdot 4$ & $2 \cdot 0$ & $6 \cdot 8$ & $23 \cdot 5$ & $48 \cdot 3$ & $5 \cdot 2$ & $22 \cdot 2$ \\
\hline \multirow{2}{*}{\multicolumn{2}{|c|}{ Control by fungicide (\%) }} & - & - & $69 \cdot 2$ & $40 \cdot 4$ & - & 一 & $77 \cdot 9$ & $54 \cdot 0$ \\
\hline & & \multicolumn{8}{|c|}{ Previous crop wheat } \\
\hline Avalon & & $19 \cdot 5$ & $40 \cdot 0$ & $10 \cdot 2$ & $25 \cdot 5$ & $27 \cdot 4$ & $55 \cdot 0$ & $13 \cdot 3$ & $36 \cdot 5$ \\
\hline Norman & & $35 \cdot 2$ & $63 \cdot 2$ & $14 \cdot 9$ & $36 \cdot 9$ & $24 \cdot 8$ & $48 \cdot 1$ & $7 \cdot 4$ & $27 \cdot 7$ \\
\hline Mean & & $27 \cdot 4$ & $52 \cdot 6$ & $12 \cdot 6$ & $31 \cdot 2$ & $26 \cdot 2$ & $51 \cdot 6$ & $10 \cdot 4$ & $32 \cdot 1$ \\
\hline \multicolumn{2}{|c|}{ Control by fungicide (\%) } & 一 & - & $54 \cdot 0$ & $41 \cdot 7$ & - & - & $61 \cdot 3$ & $37 \cdot 8$ \\
\hline
\end{tabular}

Table 12. Mean yields, numbers of ears, weights of 1000 dry grains and the percentages of $N$ in, and amounts of $N$ taken up by, wheat grain in 1982

\begin{tabular}{|c|c|c|c|c|c|}
\hline Whole-plot treatments & $\begin{array}{c}\text { Yield (t/ha) at } \\
85 \% \text { D.M. }\end{array}$ & $\begin{array}{c}\text { No. of } \\
\text { ears } / \mathrm{m}^{2}\end{array}$ & $\begin{array}{l}\text { Weight }(\mathrm{g}) \text { of } \\
1000 \text { dry grains }\end{array}$ & $\underset{(\%)}{N \text { in grain }}$ & $\begin{array}{c}N(\mathrm{~kg} / \mathrm{ha}) \\
\text { taken up }\end{array}$ \\
\hline \multicolumn{6}{|l|}{ Previous crop } \\
\hline Beans & $9 \cdot 91$ & 441 & 41.9 & $2 \cdot 02$ & 170.5 \\
\hline Wheat & $6 \cdot 88$ & 354 & $41 \cdot 1$ & $2 \cdot 26$ & $130 \cdot 4$ \\
\hline \multicolumn{6}{|l|}{ Variety } \\
\hline Avalon & $7 \cdot 71$ & 394 & $40 \cdot 0$ & $2 \cdot 27$ & $145 \cdot 7$ \\
\hline Norman & $9 \cdot 08$ & 401 & $43 \cdot 1$ & $2 \cdot 01$ & $155 \cdot 2$ \\
\hline \multicolumn{6}{|c|}{$50 \mathrm{~kg} \mathrm{~N} / \mathrm{ha}$ in seed bed } \\
\hline Without & $8 \cdot 14$ & 378 & 41.8 & $2 \cdot 13$ & $144 \cdot 6$ \\
\hline With & $8 \cdot 65$ & 417 & $41 \cdot 3$ & $2 \cdot 15$ & $156 \cdot 3$ \\
\hline \multicolumn{6}{|c|}{ Aphicide and fungicides } \\
\hline Without & $8 \cdot 12$ & 395 & $40 \cdot 5$ & $2 \cdot 13$ & $144 \cdot 8$ \\
\hline With & $8 \cdot 67$ & 400 & $42 \cdot 6$ & $2 \cdot 15$ & $156 \cdot 1$ \\
\hline S.E. & 0.033 & $4 \cdot 1$ & 0.21 & 0.011 & $1 \cdot 10$ \\
\hline
\end{tabular}

Subplot treatments

$\mathrm{N}$ dressing in spring

$\begin{array}{clcccc}\text { Divided } & 8.52 & 408 & 41.6 & 2.11 & 151.4 \\ \text { Single } & 8.27 & 387 & 41.5 & 2 \cdot 17 & 149.5 \\ \text { S.E. } & 0.056 & 8.5 & 0.18 & 0.017 & 1.55\end{array}$

$\begin{array}{cc}\mathrm{N}(\mathrm{kg} / \mathrm{ha}) \text { in spring } & \\ 0 & \mathbf{5 . 0 5} \\ 100 & \mathbf{7 . 8 2} \\ 130 & \mathbf{8 . 2 4} \\ 160 & \mathbf{8 . 6 8} \\ 190 & \mathbf{8 . 8 5} \\ \text { S.E. } & 0.079\end{array}$

$\begin{array}{rccr}309 & 42 \cdot 6 & 1 \cdot 56 & 66 \cdot 1 \\ 394 & 41 \cdot 6 & 2 \cdot 00 & 129 \cdot 9 \\ 391 & 41 \cdot 5 & 2 \cdot 11 & 143 \cdot 9 \\ 394 & 41 \cdot 7 & 2 \cdot 17 & 158 \cdot 6 \\ 411 & 41 \cdot 3 & 2 \cdot 28 & 169 \cdot 4 \\ 12 \cdot 0 & 0.25 & 0.024 & 2 \cdot 19\end{array}$


Table 13. Mean yields, numbers of ears, weights of 1000 dry grains and the percentages of $N$ in, and amounts of $N$ taken up by, wheat grain in 1983

\begin{tabular}{|c|c|c|c|c|c|}
\hline Whole-plot treatments & $\begin{array}{c}\text { Yield (t/ha) at } \\
85 \% \text { D.M. }\end{array}$ & $\begin{array}{c}\text { No. of } \\
\text { ears } / \mathrm{m}^{2}\end{array}$ & $\begin{array}{l}\text { Weight }(\mathrm{g}) \text { of } \\
1000 \text { dry grains }\end{array}$ & $\begin{array}{c}\mathrm{N} \text { in grain } \\
(\%)\end{array}$ & $\begin{array}{l}N(\mathrm{~kg} / \mathrm{ha}) \\
\text { taken up }\end{array}$ \\
\hline $\begin{array}{l}\text { Previous crop } \\
\text { Beans } \\
\text { Wheat }\end{array}$ & $\begin{array}{r}10 \cdot 50 \\
9 \cdot 63\end{array}$ & $\begin{array}{l}453 \\
438\end{array}$ & $\begin{array}{l}42 \cdot 4 \\
39 \cdot 1\end{array}$ & $\begin{array}{l}1 \cdot 70 \\
2 \cdot 00\end{array}$ & $\begin{array}{l}152.1 \\
162.6\end{array}$ \\
\hline $\begin{array}{l}\text { Variety } \\
\text { Avalon } \\
\text { Norman }\end{array}$ & $\begin{array}{r}9 \cdot 39 \\
10 \cdot 74\end{array}$ & $\begin{array}{l}445 \\
446\end{array}$ & $\begin{array}{l}38 \cdot 2 \\
43 \cdot 3\end{array}$ & $\begin{array}{l}1 \cdot 95 \\
1 \cdot 74\end{array}$ & $\begin{array}{l}155.2 \\
159.5\end{array}$ \\
\hline $\begin{array}{l}40 \mathrm{~kg} \mathrm{~N} / \mathrm{ha} \text { in } \mathrm{se} \\
\text { Without } \\
\text { With }\end{array}$ & $\begin{array}{r}9 \cdot 91 \\
10 \cdot 22\end{array}$ & $\begin{array}{l}443 \\
449\end{array}$ & $\begin{array}{l}40 \cdot 5 \\
41 \cdot 0\end{array}$ & $\begin{array}{l}1.85 \\
1.85\end{array}$ & $\begin{array}{l}155 \cdot 1 \\
159 \cdot 5\end{array}$ \\
\hline $\begin{array}{l}\text { Aphicide and fun } \\
\text { Without } \\
\text { With } \\
\text { S.E. }\end{array}$ & $\begin{array}{r}\text { ngicides } \\
9 \cdot 83 \\
10 \cdot 30 \\
0 \cdot 105\end{array}$ & $\begin{array}{l}437 \\
455 \\
10 \cdot 31\end{array}$ & $\begin{array}{c}39 \cdot 9 \\
41 \cdot 6 \\
0 \cdot 27\end{array}$ & $\begin{array}{l}1.84 \\
1.86 \\
0.021\end{array}$ & $\begin{array}{r}152 \cdot 8 \\
161 \cdot 8 \\
3.11\end{array}$ \\
\hline $\begin{array}{l}\text { Subplot treatments } \\
\text { N dressing in spr } \\
\text { Divided } \\
\text { Single }\end{array}$ & $\begin{array}{r}\text { ring } \\
10 \cdot 20 \\
9 \cdot 93\end{array}$ & $\begin{array}{l}462 \\
429\end{array}$ & $\begin{array}{l}40 \cdot 8 \\
40 \cdot 7\end{array}$ & $\begin{array}{l}1.80 \\
1.89\end{array}$ & $\begin{array}{l}155 \cdot 9 \\
158 \cdot 8\end{array}$ \\
\hline s.e. & $0 \cdot 063$ & $6 \cdot 61$ & $0 \cdot 18$ & 0.011 & 1.22 \\
\hline $\begin{array}{c}N(\mathrm{~kg} / \mathrm{ha}) \text { in spri } \\
0 \\
130 \\
160 \\
190 \\
220\end{array}$ & $\begin{array}{r}4 \cdot 41 \\
9 \cdot 63 \\
9 \cdot 96 \\
10 \cdot 23 \\
10 \cdot 43\end{array}$ & $\begin{array}{l}282 \\
431 \\
429 \\
449 \\
475\end{array}$ & $\begin{array}{l}41 \cdot 6 \\
41 \cdot 8 \\
41 \cdot 0 \\
40 \cdot 3 \\
40 \cdot 0\end{array}$ & $\begin{array}{l}1.38 \\
1.68 \\
1.79 \\
1.91 \\
2.01\end{array}$ & $\begin{array}{r}50 \cdot 8 \\
136 \cdot 9 \\
150 \cdot 2 \\
164 \cdot 7 \\
177 \cdot 5\end{array}$ \\
\hline S.E. & 0.088 & $9 \cdot 46$ & 0.25 & 0.016 & 1.72 \\
\hline
\end{tabular}

in both years, the greatest effect on total yield was given by the nitrogen fertilizer applied in spring, followed by beans instead of wheat as the previous crop. In 1982 these larger yields after beans were reflected in larger nitrogen uptakes, even though $60 \mathrm{~kg} / \mathrm{ha}$ less $\mathrm{N}$ had been given than to wheat following wheat. In 1983 this was not so, presumably because take-all was less damaging; the amounts of $\mathbf{N}$ taken up were similar after the two crops. The ears represented more than half of the total dry weight at this stage and contained about two-thirds of the N. So in mid-July the weight of dry ears, on plots given the most favourable treatment, was greater than $8 \mathrm{t} / \mathrm{ha}$ and these ears contained more than $120 \mathrm{~kg} \mathrm{~N} / \mathrm{ha}$.

\section{$Y$ ields of grain and the components of yield}

Single-factor effects. Table 12 shows that, in 1982, the factors which had significantly increased yield in July (Appendix Table 3) also significantly increased grain yields in August, with the tendency for the magnitude of these effects to increase with time. Thus, the effect of previous crop, the differ- ence between the two varieties, and the benefit from the aphicide plus fungicides were larger at harvest than in July. These increases in yield were reflected in more ears, significantly more after beans than after wheat, although percentage survival was the same after both crops. So evidently all those factors which were increasing the number of shoots (Table 8) were also increasing their sur. vival and so that of ears. Interestingly, however, the maximum number of ears corresponded only to the minimum number generally considered ad. equate for a moderate yield. Of the 400 seeds sown per $\mathrm{m}^{2}$, approximately 200 produced plants which survived over winter; these plants produced ap. proximately 800 shoots, of which 400 survived to produce ears. Relative to these gross losses the effects of the treatments tested were remarkably small. The weight of 1000 grains differed most with variety (Norman 43.1; Avalon 40.0). It was increased by $5 \cdot 2 \%$ by the aphicide and fungicide sprays and by $1.9 \%$ by beans as the preceding crop, but decreased by nitrogen fertilizer whenever it was applied.

Table 13 gives comparable data from the 1983 
Table 14. Mean yields ( $t / h a$ ) of grain (85\% D.M.) given by $N$ applied in the seed bed in the presence of increasing amounts of $N$ applied in spring, in 1982 and 1983

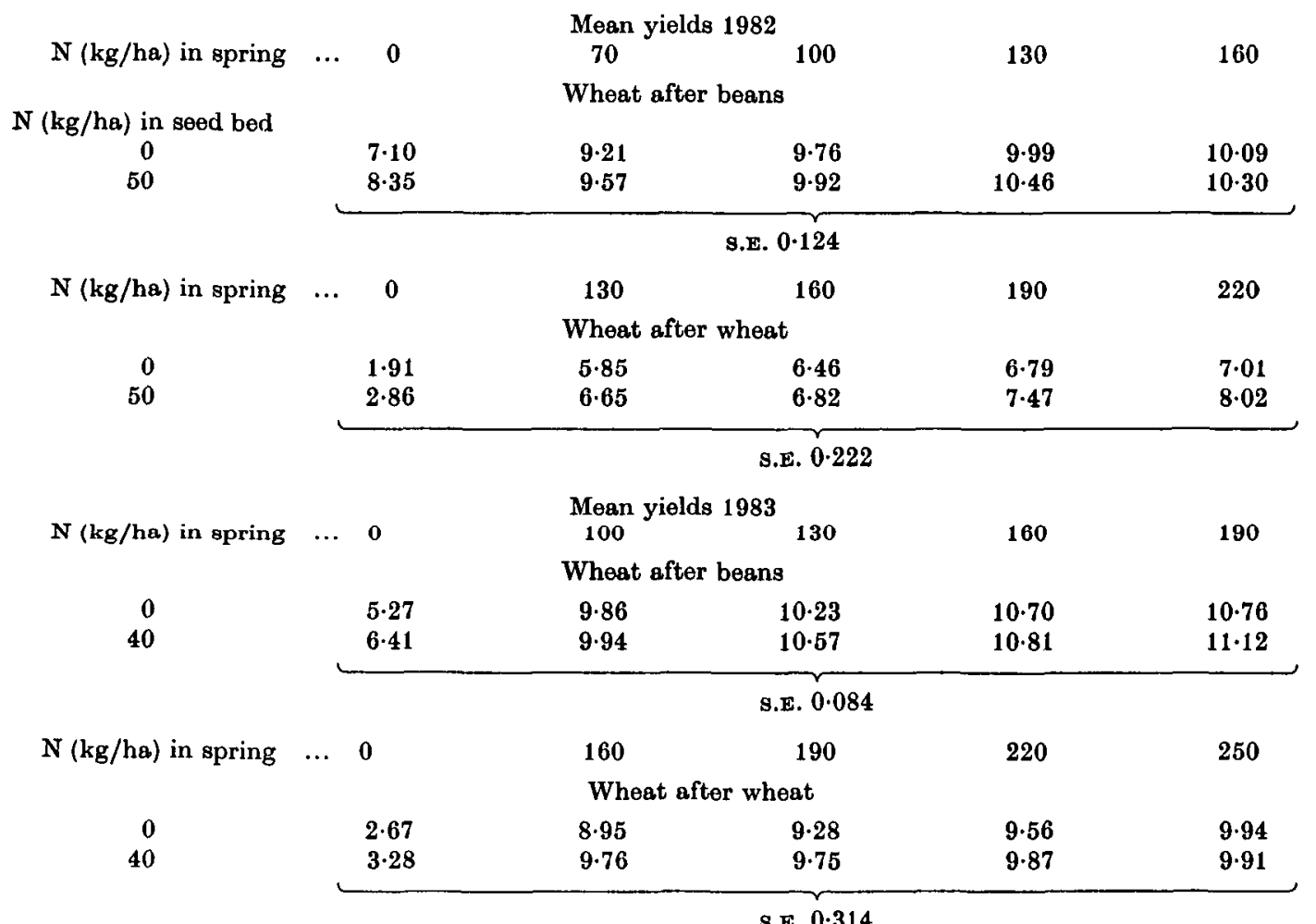

S.E. $0 \cdot 314$

experiment. Again there was a good relationship between the effects of the treatments in July (Appendix Table 3) and their effect on grain yield at harvest. The effects of previous cropping, of pathogen control and of variety were again larger at harvest than during grain filling, whilst the effect of divided dressings of $\mathrm{N}$ was smaller. Yields in 1983 were larger than those obtained in 1982 , with a mean yield after beans of $10.50 \mathrm{t} / \mathrm{ha}$ and after wheat of $9.63 \mathrm{t} / \mathrm{ha}$. Take-all was less severe in 1983 (Table 9) and this may partially explain why yields of wheat after wheat were larger in 1983 than in 1982. Consequently whilst mean yields without nitrogen were similar in the 2 years $(5.05 \mathrm{t} / \mathrm{ha}$ in $1982,4.41$ in 1983) both the response to nitrogen and the yields with most nitrogen were larger in $1983(10.43 \mathrm{t} / \mathrm{ha})$ than in $1982(8.85 \mathrm{t} / \mathrm{ha})$ (Tables 12 and 13).

Two-factor interactions. Table 14 shows that nitrogen applied in the seed bed (as 'Nitro-Chalk') always increased the yield of grain, both when the wheat followed wheat, i.e. when the soil contained little mineral $\mathrm{N}$, and when it followed beans, when the soil contained more $N$. In general the effect of
$\mathrm{N}$ in the seed bed was largest where nitrogen fertilizer was not given in spring and diminished with each additional increment of $\mathrm{N}$. However, in 1982, in wheat following wheat, the benefit from the seed-bed $\mathrm{N}$ was maintained throughout the range of $\mathrm{N}$ dressings applied in spring, suggesting that it had encouraged extra growth of roots during winter.

Table 15 shows that the benefit from giving two top-dressings in spring, i.e. one in March and the other in April, rather than one in April (Table 2), was small, a maximum of $0.40 \mathrm{t} / \mathrm{ha}$ after wheat and only $0.18 \mathrm{t}$ after beans. Thus, although early $\mathrm{N}$ sizeably increased the number of shoots in April (Table 8) and the number of ears and dry weight in July, the final effect at harvest was small. Of all the factors tested, this one had the smallest effect on yield, confirming that nitrogen amount and not timing is of prime importance.

Previous cropping interacted not only with the timing of $\mathrm{N}$ top-dressings in spring, but also with the choice of variety (Table 16) for whilst the yield of the bread-making wheat Avalon was only a little smaller $(-0.50 \mathrm{t} / \mathrm{ha})$ than that of the feeding 
Table 15. Yields $(t / h a)$ of wheat grain ( $85 \%$ D.M.) following either beans or wheat, given either single (S) or divided (D) dressings of fertilizer $-N$ in spring, 1980-3

Year $\ldots$

Previous crop ...

$\mathrm{N}$ dressing in spring

Divided (D)

Difference (D-S)

s.E. of difference

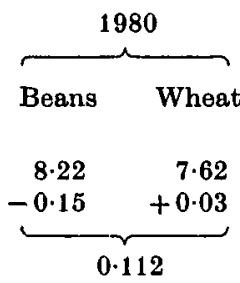

$0 \cdot 112$
1981

Beans

9.40
+0.03
0.079

1982

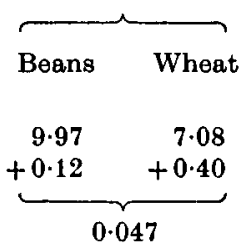

1983

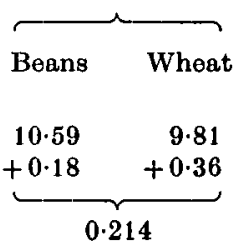

Table 16. Yields of grain, and the components of yield, of the varieties Avalon and Norman in 1982 and in 1983, grown after either beans or wheat in the previous year

\begin{tabular}{|c|c|c|c|c|}
\hline \multirow[b]{2}{*}{ Variety $\ldots$} & \multicolumn{2}{|c|}{1982} & \multicolumn{2}{|c|}{1983} \\
\hline & Avalon & Norman & Avalon & Norman \\
\hline Previous crop & \multicolumn{3}{|c|}{ Yield ( $t /$ ha) of grain ( $85 \%$ D.M.) } & \\
\hline Beans & $9 \cdot 73$ & $10 \cdot 10$ & $10 \cdot 18$ & $10 \cdot 82$ \\
\hline Wheat & $5 \cdot 69$ & $8 \cdot 07$ & $8 \cdot 60$ & $10 \cdot 65$ \\
\hline \multirow[t]{2}{*}{ S.E. } & \multicolumn{2}{|c|}{0.079} & \multicolumn{2}{|c|}{$0 \cdot 148$} \\
\hline & \multicolumn{2}{|c|}{ No. of ears $/ \mathrm{m}$} & \multirow{3}{*}{$\begin{array}{l}461 \\
429\end{array}$} & \multirow{3}{*}{$\begin{array}{l}445 \\
447\end{array}$} \\
\hline Beans & 452 & 430 & & \\
\hline Wheat & 336 & 371 & & \\
\hline S.E. & \multicolumn{2}{|c|}{$12 \cdot 0$} & \multicolumn{2}{|c|}{$14 \cdot 5$} \\
\hline \multicolumn{5}{|c|}{ No. of grains/ear } \\
\hline Beans & $45 \cdot 1$ & $47 \cdot 0$ & $46 \cdot 7$ & $46 \cdot 8$ \\
\hline Wheat & $36 \cdot 8$ & $43 \cdot 7$ & $47 \cdot 0$ & $48 \cdot 1$ \\
\hline S.E. & \multicolumn{2}{|c|}{$1 \cdot 25$} & \multicolumn{2}{|c|}{$1 \cdot 29$} \\
\hline \multicolumn{5}{|c|}{ Weight $(\mathrm{g})$ of 1000 dry grains } \\
\hline Beans & $40 \cdot 8$ & $43 \cdot 1$ & $40 \cdot 4$ & $44 \cdot 5$ \\
\hline Wheat & $39 \cdot 3$ & $43 \cdot 0$ & $36 \cdot 1$ & $42 \cdot 2$ \\
\hline S.E. & \multicolumn{2}{|c|}{0.25} & \multicolumn{2}{|c|}{$0 \cdot 38$} \\
\hline \multicolumn{5}{|c|}{ No. of grains $/ \mathrm{m}^{2}$ (thousands) } \\
\hline Beans & $20 \cdot 3$ & $20 \cdot 0$ & $21 \cdot 4$ & $20 \cdot 7$ \\
\hline Wheat & $12 \cdot 3$ & $16 \cdot 0$ & $20 \cdot 3$ & $21 \cdot 5$ \\
\hline S.E. & \multicolumn{2}{|c|}{0.21} & \multicolumn{2}{|c|}{0.16} \\
\hline
\end{tabular}

wheat Norman when each followed beans, it was very much smaller $(-2 \cdot 22 \mathrm{t} / \mathrm{ha})$ when each followed wheat. This large difference between the two varieties, when grown as a second wheat crop, can be explained only in terms of the larger take-all disease rating of Avalon (Table 9). The effect of previous crop on the components of yield was larger in 1982 than in 1983, presumably because take-all was more damaging in 1982 . Thus there were fewer ears where wheat followed wheat in 1982 than in
1983. Also, though the number of ears differed little with variety when each followed beans, with Avalon producing the larger number, they did differ when wheat followed wheat; then Avalon produced the smaller number, especially in 1982 . These decreases in the number of ears were associated with decreases in the number of grains per ear and in the weight of 1000 grains, both of which were smaller where wheat followed wheat than where wheat followed beans. The weight of 1000 


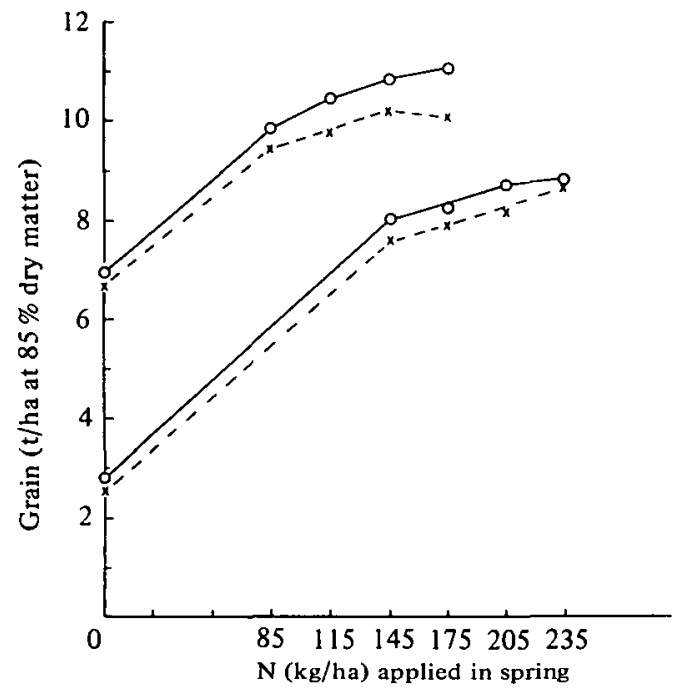

Fig. 1. The mean yields of winter wheat, following either beans (upper curves) or wheat (lower curves), 1982-3, without $(x-x)$, or with $(0-0)$, sprays to limit losses from pests and diseases. grains was used to calculate the number of grains harvested per $\mathrm{m}^{2}$. These showed (Table 16) that the losses of grain sites where wheat followed wheat were much larger in 1982 (when take-all was more severe) than in 1983 and larger with Avalon than Norman.

Three-factor interactions. Appendix Tables 4 and 5 show that for both crop sequences largest grain yields were obtained with the combination of the largest top-dressings of $\mathrm{N}$ in spring together with sprays of aphicide and fungicides to limit losses from pathogens. Surprisingly, both the absolute and the relative benefits from the sprays were larger where the wheat followed beans and there was a positive interaction between the amount of fertilizer $N$ applied and these sprays (Fig. 1). The large yields of wheat following beans and given protective sprays were associated with larger numbers of ears and with larger grains than wheat following wheat. These differences in plant structure were used to calculate the number of grains $/ \mathrm{m}^{2}$ (Appendix Tables 4 and 5). These show that after beans numbers of grains in excess of $20000 / \mathrm{m}^{2}$ were associated with grain yields of $10 \mathrm{t} / \mathrm{ha}$ or
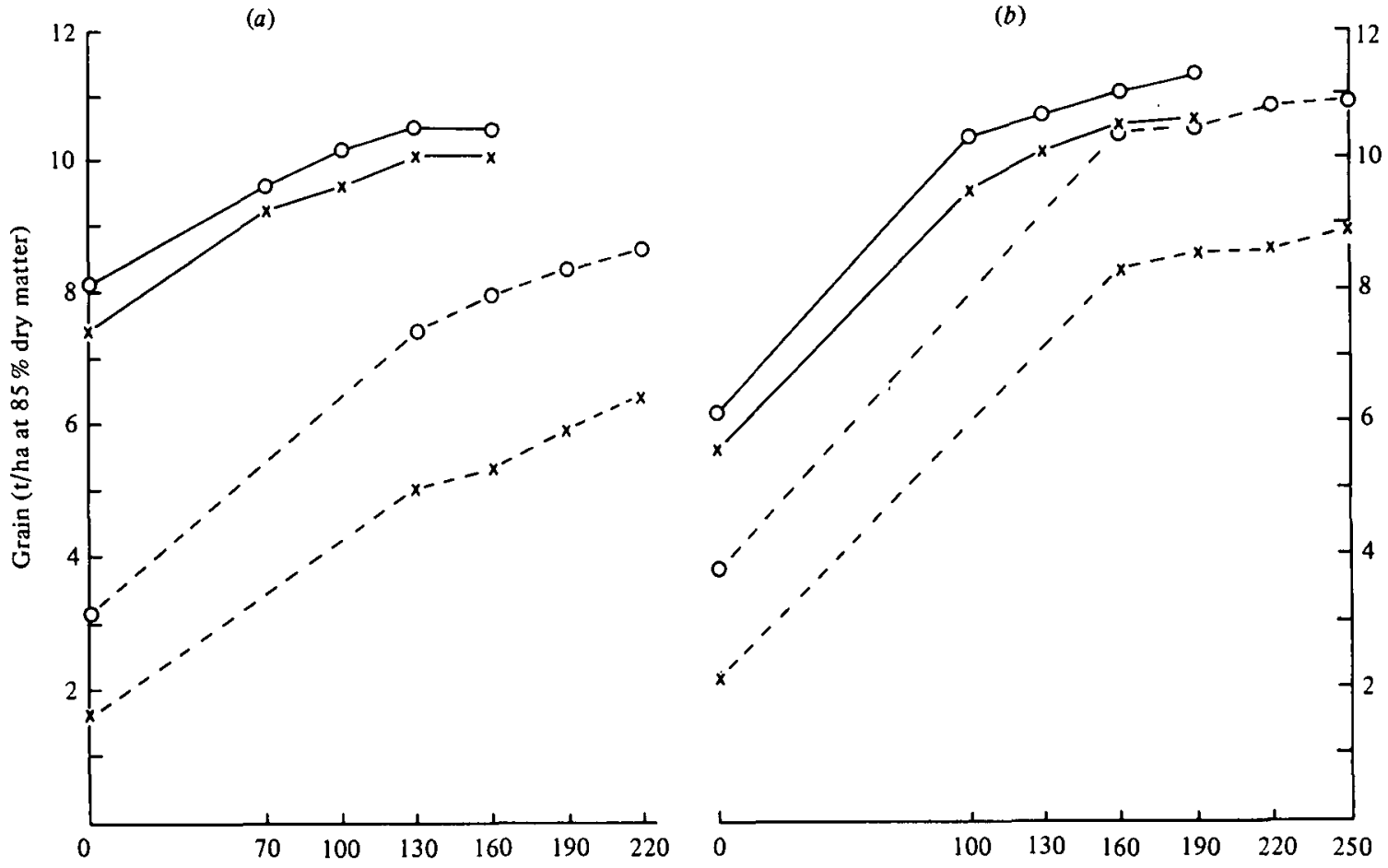

$\mathrm{N}(\mathrm{kg} / \mathrm{ha})$ applied in spring

Fig. 2. The relative grain yields of two winter wheat varieties (Avalon, $x$ or Norman, 0 ), when grown after beans (-), or after wheat (- - ). (a) In 1982 and (b) in 1983. 

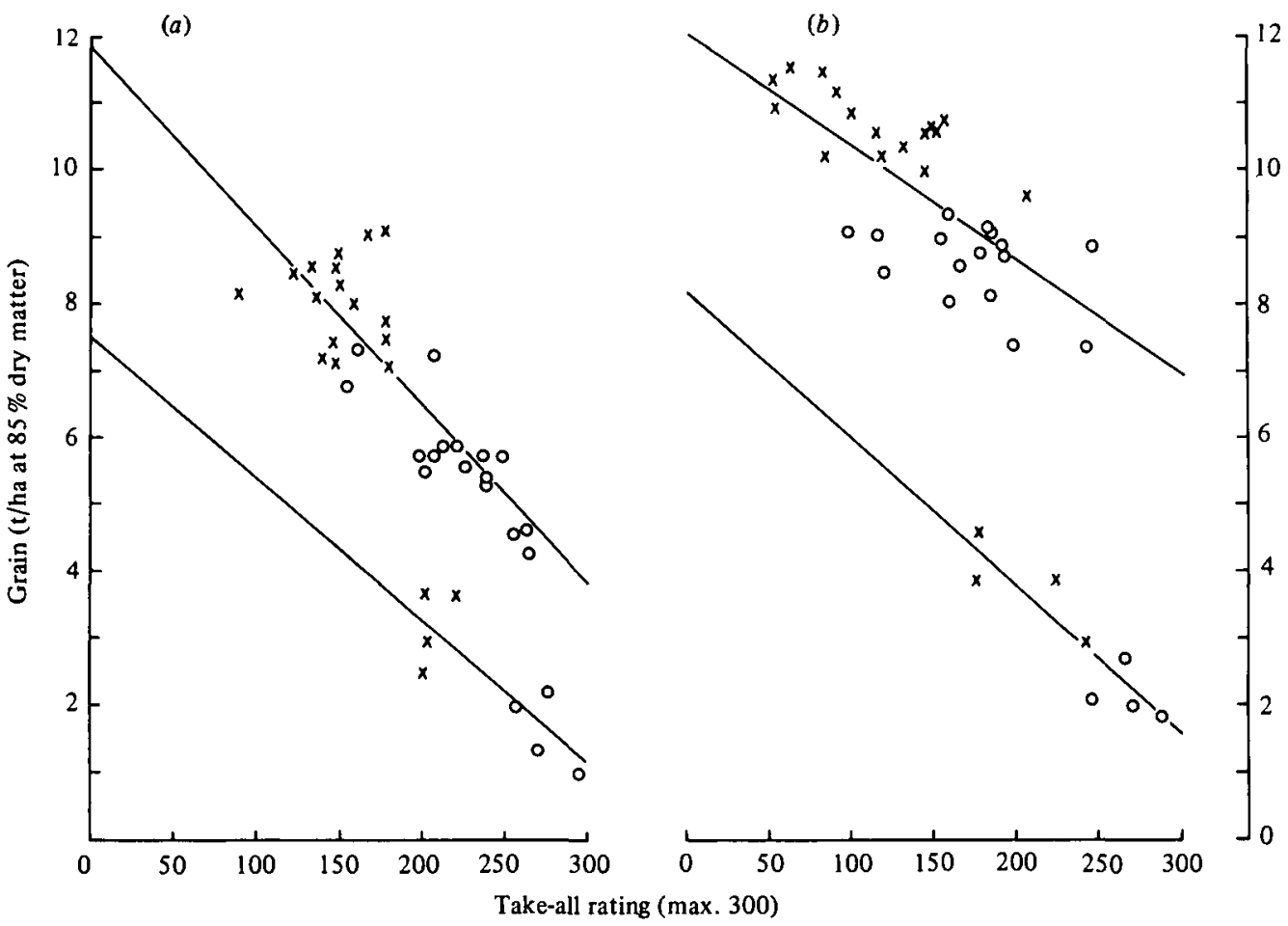

Fig. 3. The relationship between the yield of grain at harvest $(Y)$ and the take-all rating in July (X) of two winter wheat varieties (Avalon, $O$ or Norman, $x$ ). (a) In 1982, with nitrogen fertilizer (upper) $Y=11.82-0.0266 X$; without nitrogen fertilizer (lower) $Y=7 \cdot 47-0.0212 X$. (b) In 1983, with nitrogen fertilizer (upper) $Y=12 \cdot 10-0 \cdot 0172 X$; without nitrogen fertilizer (lower) $Y=8 \cdot 27-0.0224 X$.

more, but that after wheat, because 1000-grain weight was smaller, this number of grains was in. sufficient for such large yields.

The relationship between the yield of the varieties Avalon and Norman in 1982 and in 1983, both in terms of response to $\mathrm{N}$ and the effect of previous cropping, is shown in Fig. $2(a, b)$.

The 1982 data show that although the breadmaking variety Avalon had a smaller yield po. tential than the feeding variety Norman when grown after beans, the nitrogen response curves of the two varieties were similar in shape. The mean yield advantage of Norman over Avalon then, when both were protected with aphicide and fungicide sprays, was only $0.53 \mathrm{t} / \mathrm{ha}$. However, when the variety Avalon was grown after wheat, it had a far smaller yield potential than the variety Norman, even though their response curves to nitrogen fertilizer were again of similar shape. The mean yield adventage then, from growing Norman rather than Avalon, again with full pathogen control, was $2.55 \mathrm{t} / \mathrm{ha}$. This very large difference in yield may be explained in terms of the take-all disease ratings of the two varieties which were larger for Avalon than for Norman (Table 9). The regression of take- all and yield, shown in Fig. $3(a)$, shows that the take-all accounted for $\mathbf{7 1 . 4} \%$ of yield variation where nitrogen was applied and $62.6 \%$ where it was not.

In 1983, Norman again outyielded Avalon when grown after beans, but this time only by $0.21 \mathrm{t} / \mathrm{ha}$, and again their nitrogen response curves were similar in shape (Fig. 2b). Maximum yields were in excess of $11 \mathrm{t} / \mathrm{ha}$. However, when each variety was grown after wheat, Norman outyielded Avalon by $2.39 \mathrm{t} / \mathrm{ha}$. Again this large difference in yield can best be explained by the difference in take-all disease ratings (Table 9). Take-all accounted for $52.0 \%$ of the yield variation where nitrogen was applied and $\mathbf{7 8 \cdot 2} \%$ where it was not (Fig. $3 b$ ).

\section{Nitrogen contents of grain}

Percentage $\mathrm{N}$ in grain depends greatly on season and variety, and is usually inversely related to yield (Benzian \& Lane, 1979). This is well illustrated in our data (Tables 12 and 13) which show that percentage $\mathrm{N}$ was larger in 1982 than in 1983 in all comparisons. However, because grain yields were smaller in 1982 than in 1983 grain $N$ uptakes differed 


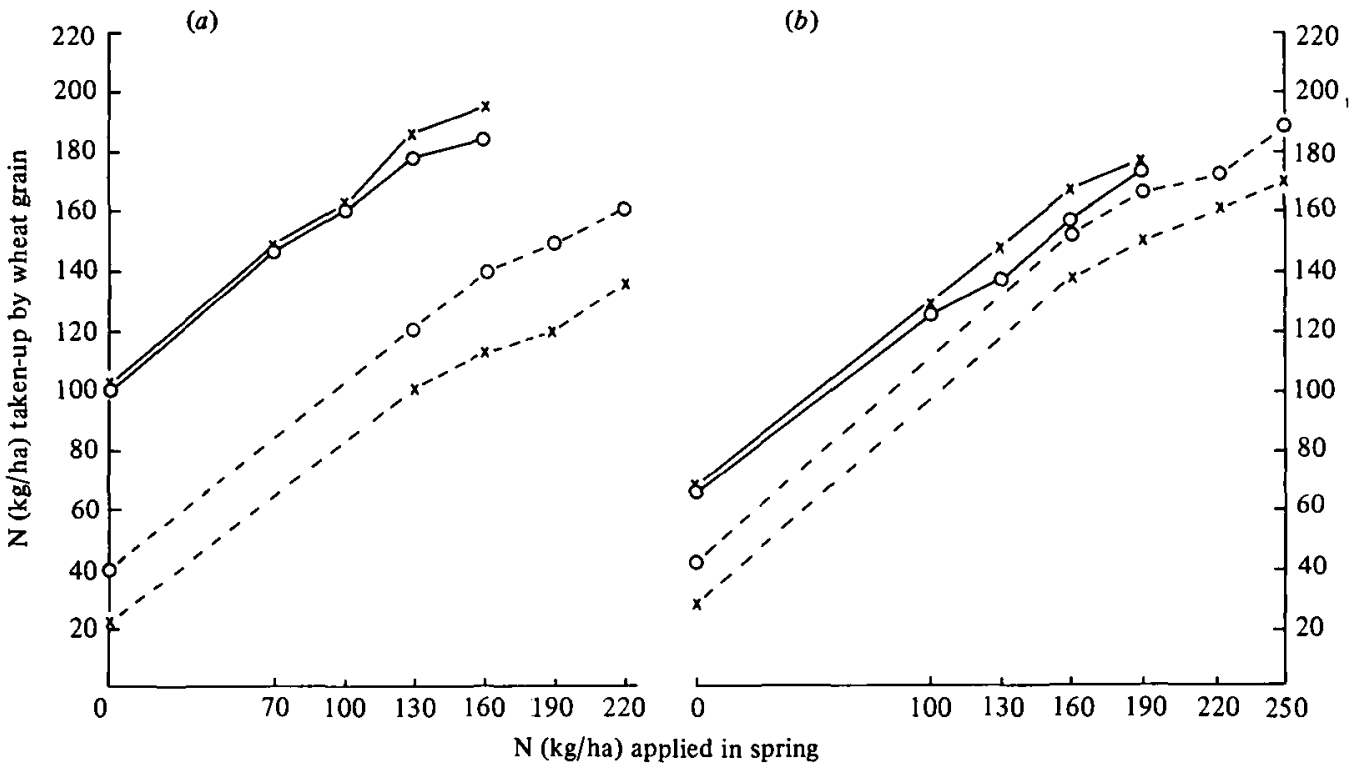

Fig. 4. The relative grain nitrogen uptakes of two winter wheat varieties (Avalon, $x$ or Norman, $O$ ), when grown after beans (-) and after wheat (-- ). (a) In 1982 and (b) in 1983.

little. Again the factor having the largest effect on the nitrogen economy of the wheat grain was previous crop, particularly in 1982. In the comparison between the varieties the bread wheat (Avalon) always contained the greater percentage of $\mathrm{N}$, but because it yielded less it removed slightly less $\mathrm{N}$ than did the feeding wheat (Norman). The aphicide and fungicide sprays increased percentage $\mathrm{N}$ in grain slightly, but because they greatly increased grain yield in both years, they significantly increased the amount of $\mathrm{N}$ taken up. Dividing the spring top-dressing of $\mathrm{N}$ into two had little effect on the total amount of $\mathrm{N}$ removed by the grain, but the single dressing of $N$ gave grain with the larger percentage of $\mathrm{N}$. Grain $\mathrm{N}$ uptake was between 50 and $60 \mathrm{~kg} / \mathrm{ha}$ where nitrogen fertilizer was not given, showing that the soil supplied only a small amount of $N$. Increasing amounts of fertilizer $N$ consistently increased the amounts of $\mathrm{N}$ in the grain. Of the largest mean amounts of fertilizer $\mathrm{N}$ applied $(190 \mathrm{~kg} / \mathrm{ha}$ in $1982,220 \mathrm{~kg} / \mathrm{ha}$ in 1983) $54 \%$ was apparently recovered by the grain in 1982 and $58 \%$ in 1983 . Given that $80 \%$ of the $\mathrm{N}$ taken up by the wheat was in the grain, this implies an apparent fertilizer $\mathrm{N}$ efficiency of about $70 \%$. The largest grain $\mathrm{N}$ uptakes $(200 \mathrm{~kg} \mathrm{~N} / \mathrm{ha}$ in 1982 and $182 \mathrm{~kg} \mathrm{~N} / \mathrm{ha}$ in 1983) were obtained where aphicide and fungicides were used (Appendix Tables 4 and 5 ). In the absence of severe take-all (after beans) Avalon removed more $\mathrm{N}$ than did Norman (Fig. 4a, $b$ ), even though the yield of grain was smaller (Fig. 2a,b). Where wheat followed wheat and take- all was more severe Avalon removed less $\mathbf{N}$ than did Norman.

\section{$Y$ ields and nitrogen contents of straw}

Yields of combine-harvested straw were measured only after beans (Appendix Tables 4 and 5) but these yields grossly underestimate the true yields (Darby, Widdowson \& Hewitt, 1984) which were probably almost twice as large. The aphicide and fungicides increased straw yields little, confirming previous observations (Penny, Widdowson \& Jenkyn, 1978) that they benefit the crop mainly during grain filling and so increase grain size. As usual, straw yields were greatly increased by nitrogen fertilizer. The percentage of $N$ in straw was never more than one third of that in grain and the maximum amounts of $\mathrm{N}$ removed were only $26 \mathrm{~kg} /$ ha in 1982 and $35 \mathrm{~kg} / \mathrm{ha}$ in 1983 . True values would therefore have been larger than this and so better estimated from grain: straw ratios obtained from sheaves of wheat cut off at ground level (Darby et al. 1984).

\section{DISCUSSION}

Since Rothamsted became responsible for the field experiments at Saxmundham, we have tried to extend the work at Rothamsted by making comparable tests under the very different soil and climatic conditions in East Suffolk. Thus, after Rothamsted began the first of a series of multifactorial experiments on winter wheat in autumn 1978, using one of the then newly available semi- 
dwarf varieties (Hustler), bred by the Plant Breeding Institute at Cambridge, we decided to make similar tests on factors limiting yield at Sax. mundham. The object was to ascertain whether the large yields obtained in 1979 on the well structured, free-draining soil at Rothamsted (Prew et al. 1983) could be reproduced on the poorly structured, tile- and mole-drained soil at Saxmundham, where there was a history of small yields (Cooke, 1975). To this end beans were grown at Saxmundham in 1979 so that tests could be made in 1980 on a semi-dwarf winter wheat variety (Virtue) grown under conditions similar to those at Rothamsted, i.e. where take-all was not likely to be damaging and where the soil would be rich in $\mathrm{N}$ in autumn.

Soil conditions at Saxmundham required a powerharrow to allow us to prepare a seed bed for sowing in September. Knowing also that large yields could depend on adequate use of both aphicide and fungicides, a combination of these two pesticides was tested, as we were not able to monitor effects other than those on yield. Sowing date and aphicide plus fungicides were tested in all combinations with amounts of nitrogen, applied both in autumn (seed bed) and in spring. The latter was of the greatest interest since it was part of our programme of work on the nitrogen requirement of winter wheat. The first experiment demonstrated that it was possible to grow $10 \mathrm{t} / \mathrm{ha}$ of wheat grain at Saxmundham, provided that the wheat followed beans, was sown in September, was given adequate $\mathrm{N}$ in spring and was protected against losses from pests and diseases. However, it appeared from the $\mathrm{N}$ response curve that not enough nitrogen had been applied in spring to obtain the maximum yield, so when the experiment was repeated in 1981 two changes were made to the design. First, it was accepted that September sowing was beneficial and so the comparison of sowing dates was replaced with a comparison of two varieties, i.e. Virtue (the variety used in 1980) and Avalon, which was the first high-yielding semidwarf wheat variety bred in the U.K. to give grain of bread-making quality. Secondly, the nitrogen scale was extended to test four amounts of $\mathrm{N}$ in spring, together with none. The other treatments were unchanged. Wet weather during summer 1981 favoured cereal foliar diseases (Lester, 1982) so it was not surprising that large yields were achieved only where aphicide and fungicides were applied. These, together with adequate top-dressings of $\mathrm{N}$ in spring $(120-200 \mathrm{~kg} / \mathrm{ha})$ produced grain yields in excess of $10 \mathrm{t} / \mathrm{ha}$, with the maxima close to $11 \mathrm{t} / \mathrm{ha}$ where $200 \mathrm{~kg} \mathrm{~N} /$ ha was given. These results confirmed that grain yields in excess of $10 \mathrm{t} / \mathrm{ha}$ could be achieved from semi-dwarf wheats grown after beans at Saxmundham provided that other restraints were removed.
In 1982, the newly recommended variety Norman was substituted for the variety Virtue, because in trials it had given larger yields, where fungicides were used, than any other variety (National Institute of Agricultural Botany, 1982). Avalon was also grown because it was still the highest yielding variety giving grain of bread-making quality, and for continuity with the new Rothamsted multifactorial experiments where Avalon was grown for the first time (Thorne et al. 1983). Also, because farmers were increasingly growing wheat after wheat (Church \& Leech, 1983), winter wheat was substituted for winter barley in our rotation which then became beans, wheat, wheat. This was done mainly to determine how the nitrogen fertilizer requirement of the two wheat crops differed and whether this could be related to measurements of mineral-N in the soil (Widdowson, Darby \& Bird, 1983). However, because we wished to avoid unforeseen residual effects from the treatments applied to the first wheat crop, we decided to repeat them all, on the same plots, for the second wheat crop. Thus, apart from the amounts of $\mathbf{N}$ applied in spring, which were larger for the second than for the first wheat crop, all other treatments and field operations on the two crops were the same.

Again maximum grain yields after beans were in excess of $10 \mathrm{t} / \mathrm{ha}$ provided that adequate nitrogen fertilizer was given and aphicide and fungicides were used. However, where wheat followed wheat, grain yields were very disappointing despite the extra $\mathbf{N}$ that was given in spring. The mean loss in yield, on plots given the best combination of treatments, was more than $3 \mathrm{t} / \mathrm{ha}$, and was far greater with Avalon than with Norman. These decreases in yield due to previous crop and variety were associ. ated with the incidence of take-all, which was more damaging than expected from previous work on this site and was more severe in successive crops of Avalon than of Norman. This was the first time that large differences in take-all between varieties had been found, so we decided to test the same experimental treatments again in 1983 by growing wheat after beans and also wheat where wheat had been grown in 1982, repeating the treatments on the same plots in the latter case. The results confirmed that large grain yields could be achieved consistently after beans, for maximum yields in excess of $11 \mathrm{t} / \mathrm{ha}$ were obtained. However, after wheat, the losses of yield from take-all were smaller in 1983 than in 1982, perhaps because the weather favoured take-all less. Nevertheless, the yield of Avalon was again very much smaller than that of Norman (mean difference $2.43 \mathrm{t} / \mathrm{ha}$ ) and this was again associated with a larger take-all rating for Avalon.

For many years Rothamsted has compared winter wheat varieties grown after either wheat or 
barley and take-all estimates have shown no consistent differences between varieties. The result from Saxmundham where Avalon after Avalon had more severe take-all than Norman after Norman was therefore unexpected. It seemed possible that Avalon was a better host for multiplying the takeall fungus after the bean break and so left more inoculum to infect the second wheat crop, and the results from the wheat seedling bioassay of soils made in September 1983 supported this view. The concept that varieties may be equally susceptible to take-all but differ in their ability to increase small populations of the take-all fungus is of agricultural importance. Clearly there is scope for further investigation to test not only different varieties, but also other cultural techniques that may limit losses from take-all. At Rothamsted, in 1982 , results from the multifactorial experiment on winter wheat, using the variety Avalon, showed that take-all was the most damaging disease, being very severe after barley but only slight after oats; it was diminished in severity both by sowing in October instead of September and by applying nitrogen early in spring (Prew, 1983).

It is evident that because the severity of take-all differed so much, we were not able directly to com. pare the nitrogen requirements of the first and second crops of wheat following beans. This will always remain a problem.

In conclusion, after small yields of both first and consecutive crops of wheat at Saxmundham in the 1960 s and average yields in the $1970 \mathrm{~s}$, best yields from 1980 to 1983 exceeded $10 \mathrm{t} /$ ha each year with a maximum of $11.5 \mathrm{t} / \mathrm{ha}$ in 1983 . Therefore the original aim of increasing yields at Saxmundham to the same level as those at Rothamsted was achieved. We believe that this was because the factors shown to be of greatest importance in the Rothamsted multifactorial experiments on winter wheat (Prew et al. 1983) were of equal importance at Saxmundham. Thus the lessons learned at Rothamsted on a freely drained soil were applicable to the heavier tile- and mole-drained soil at Saxmundham.

We thank V. Cosimini for chemical analyses, E. Bird and P. A. Cundill for dry matter determinations and preparation of crop samples, A. D. Todd for statistical analyses and V.C. Woolnough and others who helped with the experiments. 
Appendix Table 1. Yields and $N$ contents of grain and straw, numbers of ears, weights of 1000 dry grains and numbers of grains from applying four amounts of $N$ to winter wheat either unsprayed or sprayed with aphicide and fungicides in 1980

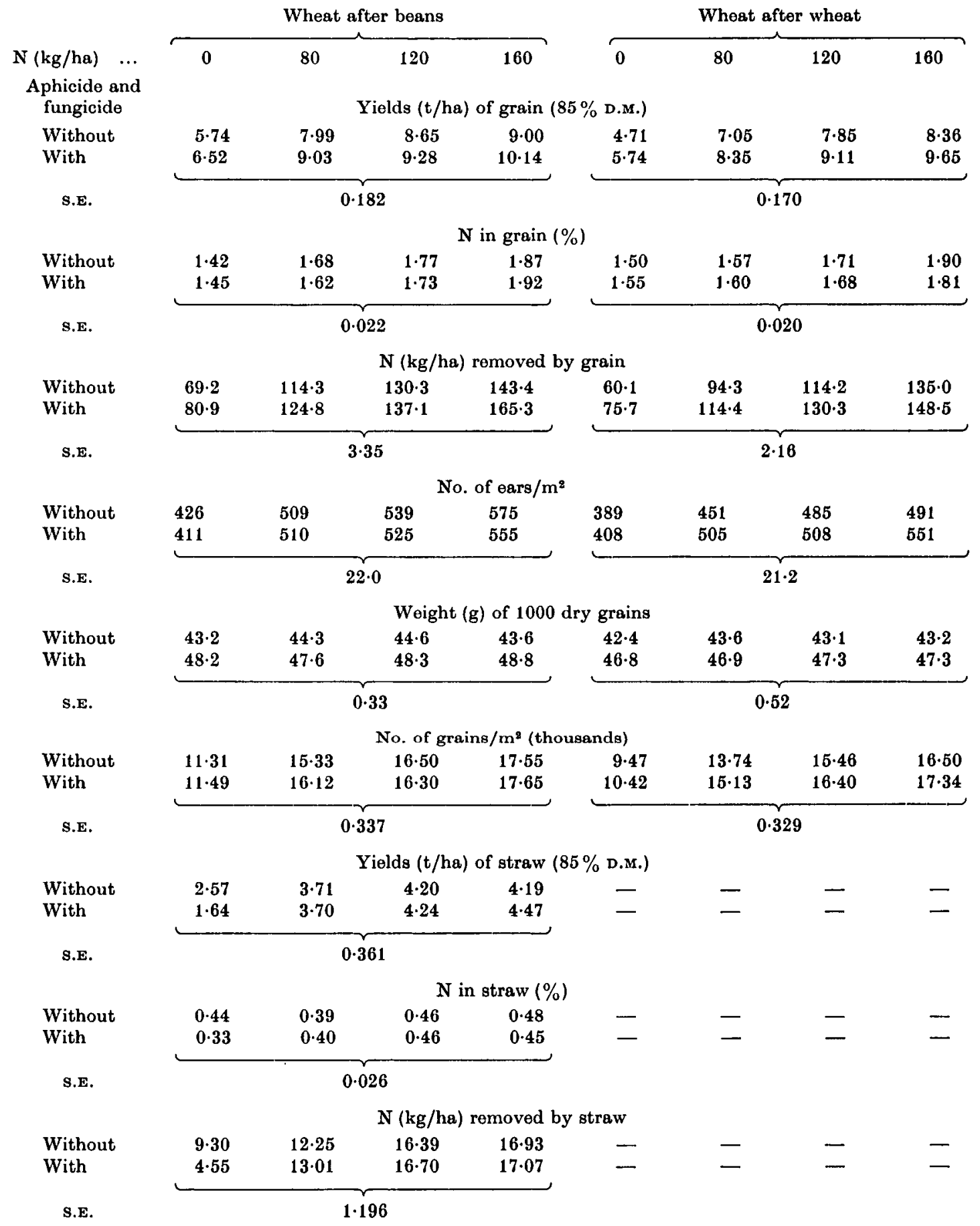


Appendix Table 2. Yields and $N$ contents of grain and straw, numbers of ears, weights of 1000 dry grains and numbers of grains from applying five amounts of $N$ to winter wheat either unsprayed or sprayed with aphicide and fungicides in 1981

\begin{tabular}{|c|c|c|c|c|c|}
\hline \multicolumn{6}{|c|}{ Wheat after beans } \\
\hline $\mathrm{N}(\mathrm{kg} / \mathrm{ha}) \quad \ldots$ & 0 & 80 & 120 & 160 & 200 \\
\hline $\begin{array}{l}\text { Aphicide and } \\
\text { fungicide }\end{array}$ & \multicolumn{4}{|c|}{ Yields (t/ha) of grain ( $85 \%$ D.M.) } & \multirow{3}{*}{$\begin{array}{r}8 \cdot 51 \\
10 \cdot 91\end{array}$} \\
\hline Without & $6 \cdot 70$ & $8 \cdot 15$ & $8 \cdot 51$ & $8 \cdot 69$ & \\
\hline With & 6.59 & $\mathbf{9 \cdot 4 3}$ & $10 \cdot 24$ & $10 \cdot 63$ & \\
\hline S.E. & \multicolumn{5}{|c|}{$0 \cdot 112$} \\
\hline \multicolumn{6}{|c|}{$\mathrm{N}$ in grain $(\%)$} \\
\hline Without & 1.51 & 1.60 & 1.74 & 1.91 & $2 \cdot 02$ \\
\hline With & $1 \cdot 46$ & 1.56 & 1.64 & 1.78 & 1.82 \\
\hline S.E. & \multicolumn{5}{|c|}{$0 \cdot 026$} \\
\hline \multicolumn{6}{|c|}{$\mathrm{N}(\mathrm{kg} / \mathrm{ha})$ removed by grain } \\
\hline Without & $85 \cdot 9$ & $111 \cdot 4$ & $126 \cdot 3$ & $141 \cdot 6$ & $146 \cdot 1$ \\
\hline With & $80 \cdot 9$ & $124 \cdot 7$ & $143 \cdot 2$ & $160 \cdot 3$ & $168 \cdot 5$ \\
\hline S.E. & \multicolumn{5}{|c|}{$\mathbf{3 \cdot 3 5}$} \\
\hline \multicolumn{6}{|c|}{ No. of ears $/ \mathrm{m}^{8}$} \\
\hline Without & 355 & 490 & 505 & 518 & 564 \\
\hline With & 418 & 513 & $\mathbf{5 3 5}$ & 528 & 581 \\
\hline S.E. & \multicolumn{5}{|c|}{$23 \cdot 0$} \\
\hline \multicolumn{6}{|c|}{ Weight (g) of 1000 dry grains } \\
\hline Without & $43 \cdot 1$ & $39 \cdot 6$ & $38 \cdot 3$ & $37 \cdot 0$ & $35 \cdot 5$ \\
\hline With & $\mathbf{4 4 \cdot 9}$ & $45 \cdot 0$ & 44.1 & 44.5 & $43 \cdot 4$ \\
\hline S.E. & & & 0.36 & & \\
\hline \multicolumn{6}{|c|}{ No. of grains $/ \mathrm{m}^{2}$ (thousands) } \\
\hline Without & $13 \cdot 25$ & $17 \cdot 54$ & $18 \cdot 88$ & $19 \cdot 97$ & $20 \cdot 38$ \\
\hline With & $12 \cdot 49$ & $17 \cdot 76$ & $19 \cdot 75$ & $20 \cdot 32$ & $21 \cdot 38$ \\
\hline S.E. & \multicolumn{5}{|c|}{$0 \cdot 224$} \\
\hline \multicolumn{6}{|c|}{ Yields $(t / h a)$ of straw ( $85 \%$ D.M.) } \\
\hline Without & $3 \cdot 27$ & $4 \cdot 17$ & $4 \cdot 35$ & $4 \cdot 45$ & $4 \cdot 73$ \\
\hline With & 3.33 & $4 \cdot 69$ & $4 \cdot 78$ & $5 \cdot 24$ & $6 \cdot 42$ \\
\hline S.E. & & & $0 \cdot 148$ & & \\
\hline \multicolumn{6}{|c|}{$\mathrm{N}$ in straw $(\%)$} \\
\hline Without & $0 \cdot 33$ & 0.43 & 0.51 & 0.59 & $0 \cdot 68$ \\
\hline With & $0 \cdot 28$ & $0 \cdot 34$ & 0.39 & $0 \cdot 46$ & 0.52 \\
\hline S.E. & & & 0.021 & & \\
\hline \multicolumn{6}{|c|}{$\mathrm{N}(\mathrm{kg} / \mathrm{ha}$ ) removed by straw } \\
\hline Without & $9 \cdot 14$ & $15 \cdot 33$ & $19 \cdot 08$ & $22 \cdot 48$ & $27 \cdot 66$ \\
\hline With & $8 \cdot 00$ & $13 \cdot 79$ & $15 \cdot 96$ & $20 \cdot 47$ & $24 \cdot 08$ \\
\hline S.E. & & & 0.827 & & \\
\hline
\end{tabular}




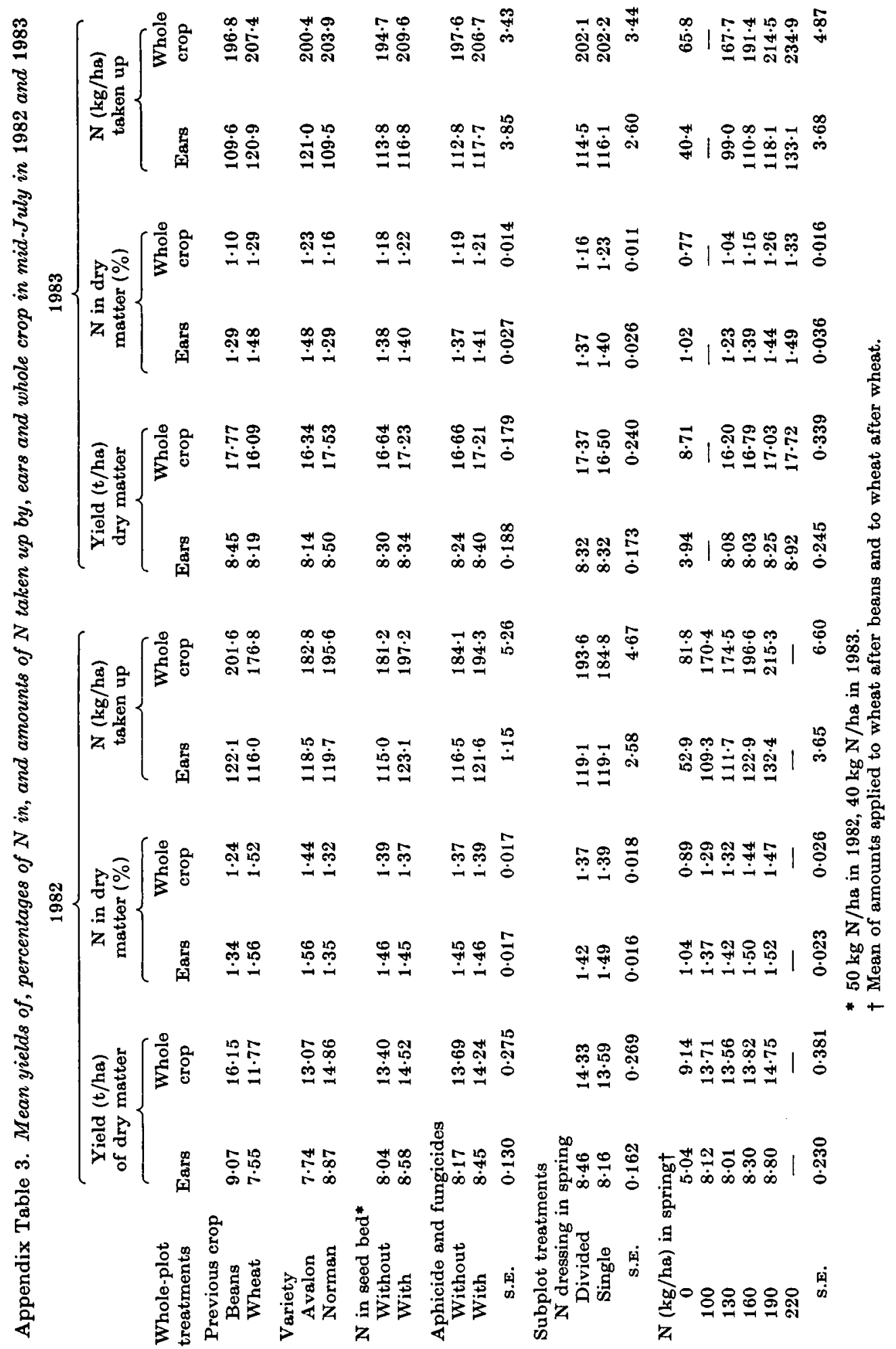




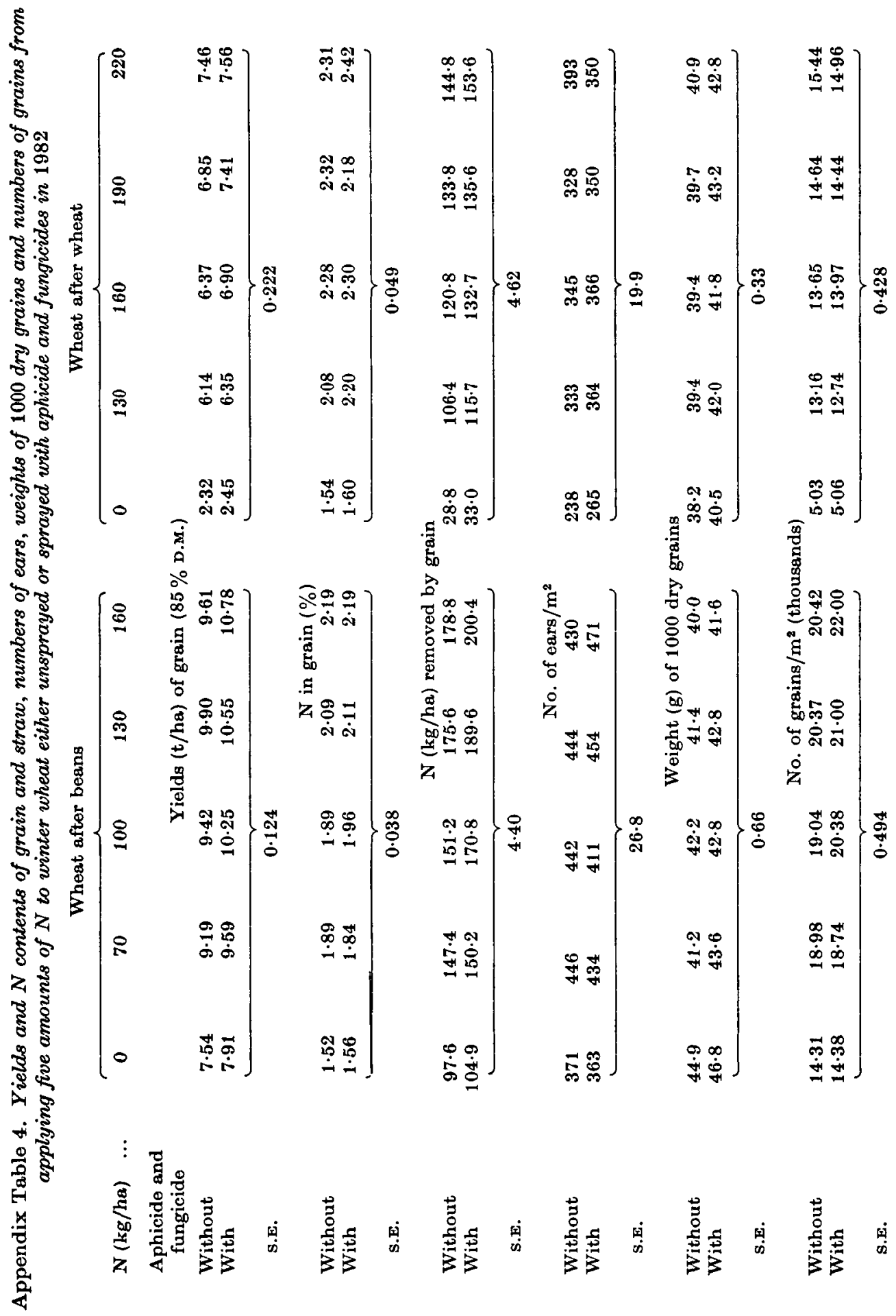




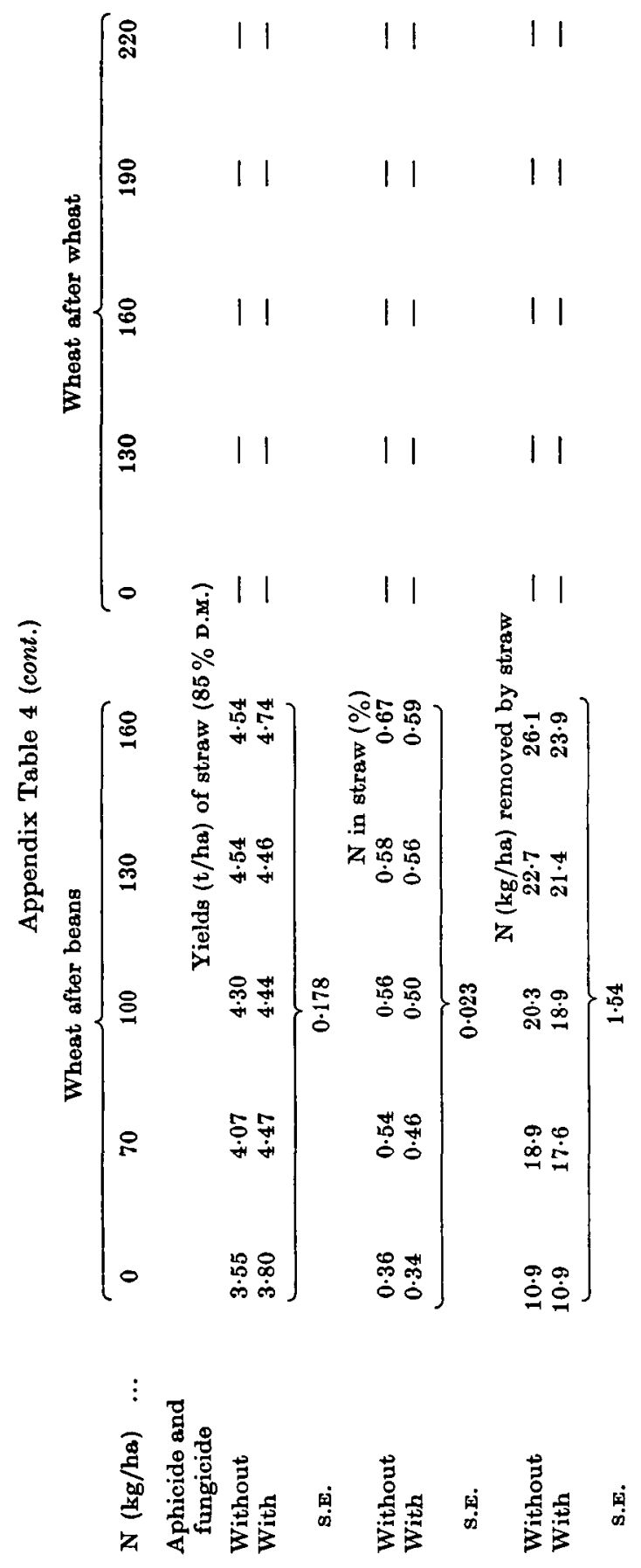




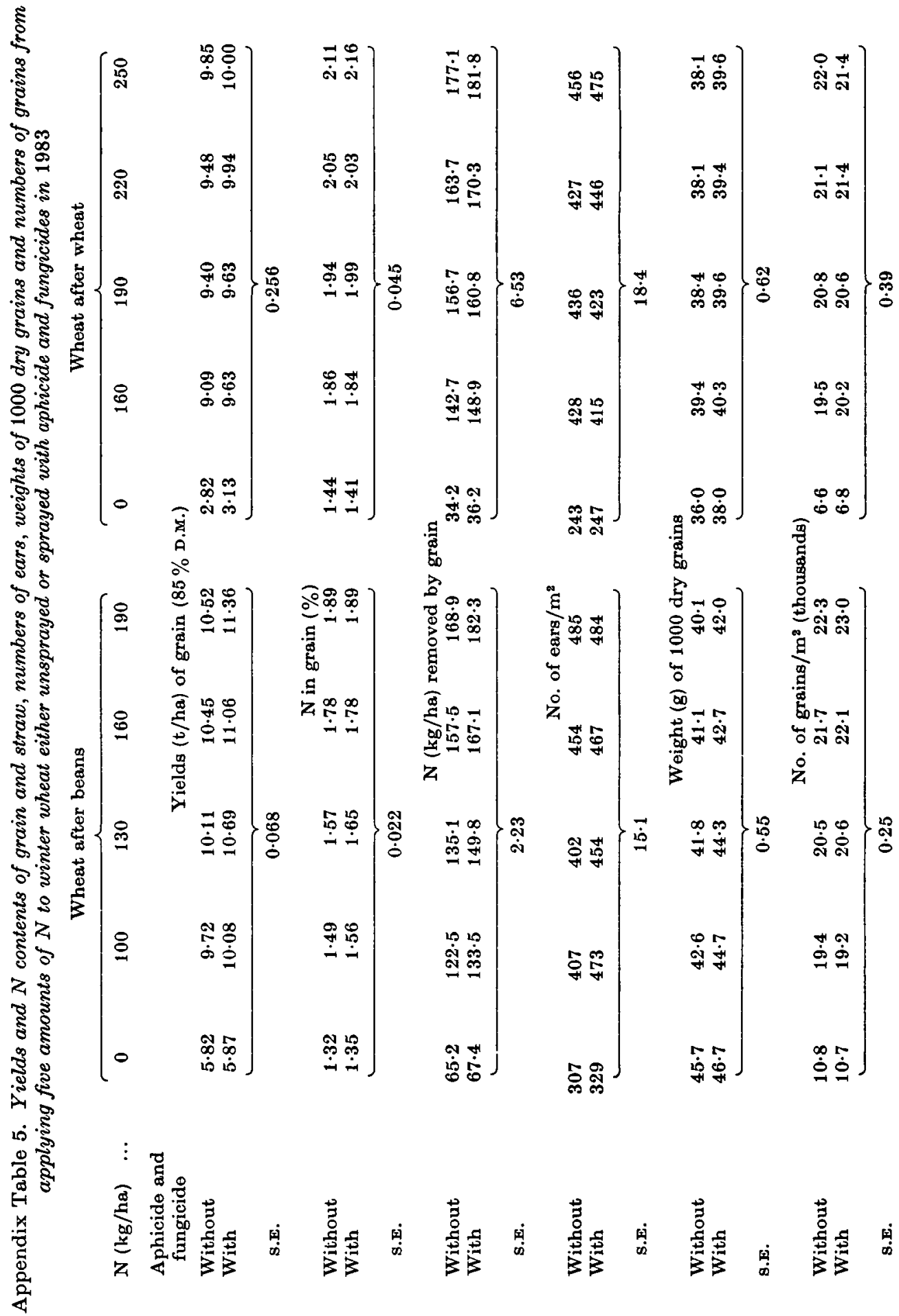




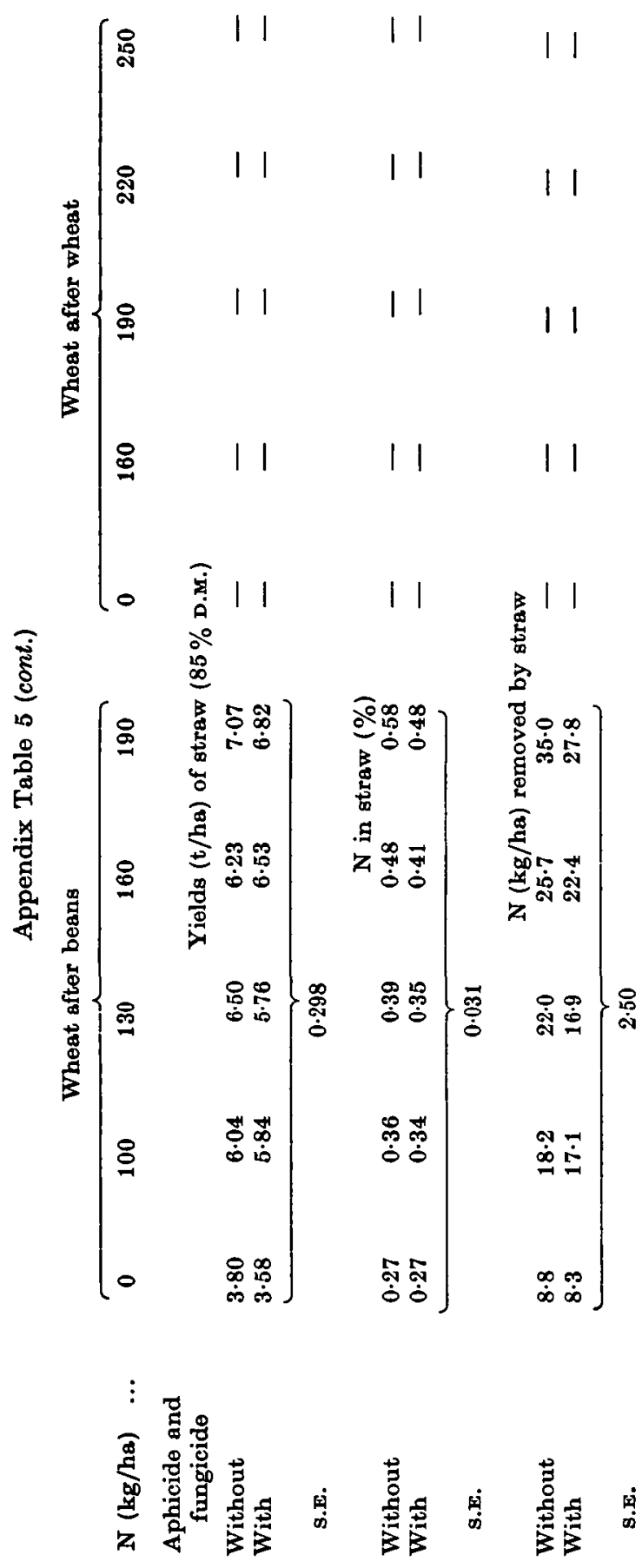




\section{REFERENCES}

Benzian, B. \& Lane, P. (1979). Some relationships between grain yield and grain protein of whea.t experiments in south-east England and comparisons with such relationships elsewhere. Journal of the Science of Food and Agriculture 30, 59-70.

Church, B. M. \& Leech, P. K. (1983). Fertiliser use on farm crops in England and Wales, 1982, p. 8. London: Ministry of Agriculture, Fisheries and Food (SS/ $\mathrm{CH} / 11$ ).

Cooke, G. W. (1975). The achievements of ten years work at Saxmundham Experimental Station. Rothamsted Experimental Station, Report for 1974, Part 2, pp. 187-194.

DarbY, R. J., Widdowson, F. V. \& HewiTT, M. V. (1984). Comparisons between the establishment, growth and yield of winter wheat on three clay soils, in experiments testing nitrogen fertilizer in combina. tion with aphicide and fungicides, from 1980 to 1982. Journal of Agricultural Science, Cambridge 103, 595611.

Hodae, C. A. H. (1972). The soils at Saxmundham Experimental Station. Rothamsted Experimentat Station, Report for 1971, Part 2, pp. 143-148.

Lester, E. (1982). Introduction to Plant Pathology Department report. Rothamsted Experimental Station, Report for 1981, Part 1, pp. 185-187.

National Institute of Agricultural Botany (1981 and 1982). Recommended varieties of cereals. Farmers Leaflet No. 8.

Penny, A., Widdowson, F. V. \& Jenkyn, J. F. (1978). Spring top-dressings of 'Nitro-Chalk' and late sprays of a liquid $\mathrm{N}$-fertilizer and a broad spectrum fungicide for consecutive crops of winter wheat at Saxmundham, Suffolk. Journal of Agricultural Science, Cambridge 90, 505-516.

Penny, A., Widdowson, F. V. \& Jenkyn, J. F. (1983). Experiments with solid and liquid $\mathrm{N}$-fertilizers and fungicides on winter wheat at Saxmundham, Suffolk, 1976-9. Journal of Agricultural Science, Cambridge $100,163-173$.

Prew, R. D. (1983). Factors limiting yield of winter wheat; fungal diseases. Rothamsted Experimental Station, Report for 1982, Part 1, pp. 22-23.

Prew, R. D., Church, B. M., Dewar, A. M., Lacey, J., Penny, A., Plumb, R. T., Thonne, G. N., Todd,
A. D. \& Wrulams, T. D. (1983). Effects of eight factors on the growth and nutrient uptake of winter wheat and on the incidence of pests and diseases. Journal of Agricultural Science, Cambridge 100, 363382.

Slope, D. B., Etheridge, J. \& Williams, R. J. B. (1973). Grain yield and the incidence of take-all and eyespot in winter wheat grown in different crop sequences at Saxmundham. Rothamsted Experimental Station, Report for 1972, pp. 160-167.

Slope, D. B., Prew, R. D., Gutreridae, R. J. \& ETHERIDGE, J. (1979). Take-all, Gaeumannomyces graminis var. tritici, and yield of wheat grown after ley and arable rotations in relation to the occurrence of Phialophora radicicola var. graminicola. Journal of Agricultural Science, Cambridge 93, 377-389.

Thorne, G. N., Dewar, A. M., Prew, R. D., Williams, T. D., Lacey, J., Plumb, R. T., Penny, A., Church, B. M. \& TodD, A. D. (1983). Factors limiting yield of winter wheat; yield at maturity. Rothamsted Experi. mental Station, Report for 1982, Part 1, pp. 19-20.

Widdowson, F. V., Darby, R. J. \& Bird, E. (1983). Mineral nitrogen in soils under winter wheat during winter and spring. Rothamsted Experimental Station, Report for 1982, Part 1, p. 261.

Widdowson, F. V., Jenkyn, J. F. \& Penny, A. (1980 and 1981). Fungicides, $N$ and Growth Regulator. Rothamsted Experimental Station, Yields of the Field Experiments 1979, pp. 241-243; 1980, pp. 197-201.

Widdowson, F. V., Jenkyn, J. F. \& Penny, A. (1982). Results from factorial experiments testing amounts and times of granular $\mathbf{N}$-fertilizer, late sprays of liquid $\mathrm{N}$-fertilizer and fungicides to control mildew and brown rust on two varieties of spring barley at Saxmundham, Suffolk 1975-8. Journal of Agricultural Science, Cambridge 99, 377-390.

Widpowson, F. V., Johnston, A. E. \& Penny, A. (1980). Multifactorial experimentation on continuous winter wheat grown in sendy clay soil at Saxmundham, Suffolk. Journal of Agricultural Science, Cambridge 94, 155-170.

Zadoks, J. C., Chang, T. T. \& KonzaK, C. F. (1974). A decimal code for the growth stages of cereals. Weed Research 14, 415-421. 